\title{
NEGOCIAÇÃO E FORMAÇÃO DE CONTRATOS INTERNACIONAIS -- em direito francês e inglês
}

\author{
Paulo Borba Casella \\ Doutor em direito (Universidade de São Paulo Depto. Internacional) \\ d.e.s.s. em Direito do Comércio Internacional (Université de Paris X), \\ professor doutor efetivo (MS-3) do Departamento de Direito Internacional, \\ advogado em São Paulo
}

\begin{abstract}
Resumo: Vínculos pré-contratuais tais como cartas de intenções e contratos preliminares muitas vezes vão muito adiante do que pretendiam as eventuais futuras partes contratantes, durante negociações em vista de um contrato. Não há problema em caso de sucesso das negociações, considerando que os vínculos preliminares serão suplantados pelo contrato principal assinado pelas partes. Caso as negociações não tenham sucesso, contudo, as mesmas partes podem se ver vinculadas contra sua vontade em extensão dificilmente previsível, desde que ocorra a combinação certa de elementos formais e estruturais (tais como oferta e aceitação, e consideration), embora as partes pudessem não ter avaliado integralmente suas respectivas intenções de criar vínculos juridicos (podendo-se argumentar que, mesmo o silêncio, em alguns casos, pode ser considerado como equivalente à aceitação).
\end{abstract}

\begin{abstract}
Precontractual engagements such as letters of intention and preliminary commitments do often go well beyond the scope intended by the eventual contracting parties, during negotiations aiming at an agreement. No problem if negotiations succeed, since preliminary ties will be superseded by the main agreement execuited by the parties. If negotiations do not succeed, however, the same parties may find themselves unwillingly bound to a quite unexpected extent, provided the right combination of formal and structural elements (i.e., offer, acceptance and consideration) is present (it may be argued, even silence, in some cases, can be a lawful equivalent to acceptance) although the parties might not have fully envisaged their respective intention to create legal relations.
\end{abstract}

\section{Introdução} contratual

Título preliminar o direito do comércio internacional e o fenômeno cap. I - o comércio internacional, a noção de contrato e o contrato internacional

1. especificidades do comércio internacional

2. a noção de contrato

3. a noção de contrato internacional 
Primeira parte - negociação e vínculos pré-contratuais

Título I - a negociação

cap. II - técnicas de negociação e redação de contratos e escolha do idioma

1. técnicas de negociação

2. técnicas de redação

3. idioma do contrato

cap. III - desenvolvimento da negociação: tratativas

1. natureza jurídica e desenvolvimento da negociação

2. dificuldades específicas dos contratos internacionais

3. efeitos da negociação

Título II - vínculos pré-contratuais: carta de intenções e pré-contrato

cap. IV a carta de intenções

1. definição

2. pré-contrato e carta de intenções

3. efeitos da carta de intenções

cap. V - o pré-contrato

1. a noção de contrato e o pré-contrato

2. pré-contrato e noções próximas

3. extinção do pré-contrato

\section{Segunda parte - formação do contrato}

Título I - oferta e aceitação

cap. VI - oferta

1. oferta e tratativas

2. existência de oferta e seus elementos

3. efeitos da oferta -- possibilidade e conseqüências de sua revogação

cap. VII - aceitação

1. noção de aceitação

2. o silêncio vale como aceitação?

3. efeitos da aceitação e celebração do contrato 
Título II - intention to create legal relations e consideration no direito inglês

cap. VIII - intention to create legal relations

1. contratos não comerciais

2. contratos comerciais

3. crítica de WILLINSTON

cap. IX - a consideration

1. elementos fundamentais

2. definição

3. papel da consideration

\section{Conclusão}

\section{Notas}

\section{Introduçāo}

O objeto do presente estudo é a análise e comparação de aspectos do processo de negociação e formação de contratos internacionais em direito francês e inglês, ensejando, ao mesmo tempo, extrapolação comparativa mais ampla, entre sistemas (um de direito civil ou direito codificado, o direito francês, ficando subjacente a enorme influência que teve sobre os outros ordenamentos nacionais, e o outro, o sistema de common law, par excellence, o direito inglês), enfocando a análise das conseqüências jurídicas de processo equivalente e integrante da prática diária de qualquer ordenamento, a formação e funcionamento do fenômeno contratual.

O foco central de análise é a expressão do cơmpromisso das partes, e a avaliação da extensão desse compromisso, já que, muitas vezes, antes mesmo da assinatura de qualquer contrato ou documento formal, o acordo de vontades e resultante compromisso das partes pode ser muito mais sério e estar muito mais solidamente expresso do que se teria desejado. Justamente por isso é interessante destacar algumas noções e refletir sobre a sucessão, ou antes, o encadeamento dos atos que conduzem a uma eventual plena e estável embora muitas vezes, nem tão plena, nem tão estável - expressão do acordo de vontades das partes em um contrato.

Pode parecer difícil estabelecer hierarquia entre os elementos que se integrarão na formação do contrato, mas pareceu-me indispensável fazer algumas observações de ordem, digamos assim, tanto ontológicas quanto terminológicas, no título preliminar. Em seguida, a primeira parte analisa o processo de negociação e os vínculos pré-contratuais. A segunda parte, por sua vez, é dedicada ao processo de formação do contrato.

Estes são temas extremamente vastos e complexos. São também campos nos quais já se exercitou longa e proficuamente a reflexão jurídica, privilegiando sejam os aspectos civis, comerciais, internacionais, comerciais-internacionais ou 
comparatistas, tanto no exterior quanto entre nós, tanto entre os assim chamados clássicos, como recentemente. Sem esquecer tal ressalva e tal condicionante, é preciso também ter presente que estamos diante de temas a respeito dos quais dificilmente se pode pretender já ter sido dita a última palavra, e a respeito dos quais sempre se pode almejar que a reflexão auxilie a fazer aflorar novas combinações e permita confrontar diferentes pontos de vista:

\section{Título preliminar - o direito do comércio internacional e o fenômeno contratual}

O objeto do presente título preliminar é de fornecer alguns parâmetros norteando a escolha do tema da negociação e formação dos contratos internacionais dentro do àmplo universo do comércio internacional, à guisa de pontos básicos, em relação ao que se vai abordar nos capítulos seguintes, nomeadamente as noções de 'comércio internacional', de 'contrato', e do enfant terrible, o 'contrato internacional'.

\section{Capítulo I - o comércio internacional, a noção de contrato e o contrato internacional}

O que significam 'comércio internacional', 'contrato' e 'contrato internacional' são questões por demais conhecidas e complexas, e tantas vezes respondidas, para que se pretenda retomá-las aqui, neste momento. Contudo, mais do que invocar as lições de toda a doutrina e recolocar em discussão as exigências e especificidades da prática, trata-se, antes de mais nada, de levar em conta alguns elementos fundamentais dessas três noções, bem como situá-la em relação ao conjunto do texto.

O comércio internacional formula exigências específicas e de alta diversidade e especialização setoriais que é imperativo conhecer, sob pena de perda de orientação de ação (seção 1). A noção de contrato (seção 2) talvez seja um dos aspectos do direito melhor e mais detalhadamente estudados. De qualquer modo foi importante evocar alguns traços elementares para situar em face de tal conceito a noção de contato internacional (seção 3).

\section{seçảo 1 - especificidades do comércio internacional}

O término da II Guerra Mundial inaugura nova fase das relações econômicas internacionais.

Esse extraordinário desenvolvimento das relações econômicas teve de ser acompanhado por esforços consideráveis visando a regulamentação jurídica de grande número de inovações da prática, para as quais tornava-se indispensável assegurar um grau mínimo de integração entre os diferentes direitos nacionais e as normas internacionais aplicáveis.

Tais inovações passaram a integrar o vocabulário jurídico e as reflexões (muitas vezes apres coup) da doutrina, tais como os contratos turn-key ou cle-enmain, os múltiplos contratos de transferência de tecnologia, os contratos de cooperação industrial, os contratos de associação entre empresas, revestindo-se ou 
não dos contornos de joint ventures, ou a infernal parafernália dos contratos finánceiros internacionais (1). Essa evolução exigiu também o aprimoramento e a institucionalização de mecanismos de solução amigável de controvérsias, em âmbito do comércio internacional, levando institutos tais como a arbitragem a conhecer novo desempenho. Dentre as transformações dos negócios, existe aspecto que apresenta particular interesse: é a formação e o desenvolvimento da noção de contrato internacional, o instrumento indispensável e específico dos intercâmbios efetuados entre pessoas físicas e/ou jurídicas cujos centros de interesse estão situados em países distintos.

A procura de conceitos teóricos básicos no campo do direito do comércio internacional é tarefa sempre difícil e de resultados desiguais, em razão da multiplicidade de fontes de expressão e do caráter muitas vezes elementar ou destituído de regras gerais, manifestado por essas múltiplas fontes ${ }^{(3)}$.

As diferentes situações que podem conduzir à formação dos contratos no comércio internacional exprimem essa multiplicidade e essa diversidade.

O contrato internacional se destaca das categorias tradicionais, estruturadas pela doutrina clássica e, independentemente dos parâmetros válidos e aplicáveis aos contratos internos, abre novos caminhos.

\section{seção 2 - a noção de contrato}

Contrato é acordo de vontades do qual resultam obrigações, cuja execução é juridicamente exeqüível. Tal elemento o distingue dos demais acordos de vontades, não passíveis de execução forçada. Esse dado é exclusivo dos acordos aos quais a lei confere tal prerrogativa.

O contrato é normalmente concebido como um ato cuja formação, bilateral ou multilateral, exprime o consenso de tantas vontades manifestadas quantas sejam as partes contratantes.

Para definir o contrato faz-se apelo a esse aspecto: os contratos são atos jurídicos construídos por um intercâmbio de declarações.

A bilateralidade na formação do contrato -- observa Rodolfo Sacco (4) será indispensável se os efeitos do contrato são bilaterais, ou seja, se a aceitação contém, por sua vez, uma nova aceitação. A questão da formação unilateral ou bilateral do contrato somente se coloca para os contratos que tendem a impor obrigações ou encargos somente a uma das partes.

A exigência da bilateralidade na formação do contrato pode ser dividida entre dois dados distintos que, por seu turno, terão conseqüências práticas distintas:

a. o princípio da soberania formal da vontade do sujeito no campo jurídico deveria levar à conclusão de que a condição de um sujeito não pode sofrer alterações (seja para melhor ou para pior) em razão de declaração unilateral feita por outra pessoa;

b. a partir da prevenção de qualquer lesão patrimonial não justificada, dever-se-ia chegar à conclusão de que os direitos de uma pessoa não podem ser alterados para pior pela declaração unilateral de um terceiro. 
Se o legislador adota integralmente o princípio da soberania formal da vontade da pessoa sobre seus próprios direitos, haverá aplicação do princípio segundo o qual ninguém pode ter vantagens ou sofrer prejuízos senão em razão da expressão de seu consentimento. Se o legislador aceita a outra norma, o sistema jurídico adotará o princípio segundo o qual ninguém pode sofrer prejuízos sem ter exprimido seu consentimento.

Para avaliar as implicações da adoção de uma ou outra das duas soluções vale, ainda, acompanhar Rodolfo Sacco ${ }^{(5)}$ quando observa que, na medida em que a lei admite que o silêncio possa valer como aceitação, e o juiz, diante do conjunto de cirscuntâncias de um caso concreto, decide que, naquela hipótese, é possível admitir que o silêncio não poderia significar outra coisa senão a aceitação, a bilateralidade na formação do contrato não desaparece. "O silêncio, em si, é uma omissão, mas se as circunstâncias que o acompanham são fatos positivos, aptos a conferir-lhe a natureza de um meio de expressão, haverá, então, um silêncio qualificado (silenzio circostanziato) que poderia ser elencado entre as manifestações da vontade, de natureza totalmente distinta daquela do silêncio simples" ${ }^{(6)}$.

\section{seção 3 - a noção de contrato internacional}

O enfoque da matéria contratual a partir do ponto de vista estritamente enfocado no direito interno poderia justificar a conclusão de que a distinção entre o contrato interno e o contrato internacional depende exclusivamente dos elementos geográficos colocados em jogo em cada contrato.

Nesse enfoque um contrato seria internacional na medida em que envolvesse em relação jurídica elementos nacionais e estrangeiros, que o sejam em razão da diversidade de domicilio das partes, e os efeitos resultantes dessa mesma diversidade, ou em razão da nacionalidade das partes, tanto no caso da pessoas físicas quanto das pessoas jurídicas.

Tal enfoque mostrou-se totalmente insuficiente para abarcar o conjunto das exigências técnicas colocadas pelo comércio internacional.

O contrato internacional é o elemento fundamental e a ferramenta indispensável do comércio internacional. A análise do contrato internacional não pode negligenciar sua inserção no contexto das relações econômicas internacionais.

Afirmar que o contrato internacional se insere no conjunto das relações econômicas internacionais implica levar em conta os elementos não-contratuais que podem afetar a vida e o equilibrio das relações contratuais: o contexto político e econômico no qual se inscreve o contrato, as diferenças entre os sistemas jurídicos nacionais.

O contrato interno fica sujeito ao regime regulador estipulado no direito interno, e seus elementos serão territorialmente limitados, enquanto o contrato internacional é, por definição, extraterritorial.

A noção de contrato internacional apresenta dificuldades. Numerosas e complexas questões se colocam a propósito dessa noção.

A noção mais freqüentemente lembrada inclui todos os contratos que apresentam elementos de conexão com mais de um sistema jurídico nacional. 
Esse enfoque, baseado no direito internacional provado, tenderia a atribuir importância à distinção entre contrato interno e contrato internacional, com o fim único de individualizar, por meio das normas de conflito, a lei aplicável a tal contrato. Esse enfoque mostrou-se pouco satisfatório por diversas razōes, especialmente na medida em que pode levar a resultados opostos, ou, ao menos, substancialmente diversos daqueles pretendidos pelas artes, de tal forma que, dentre todos os elementos de conexão com diferentes ordenamentos jurídicos, que possam estar contidos em determinada relação jurídica, de caráter internacional, acarretando a necessidade de chegar ao dépeçage do contrato, com todos os inconvenientes que podem resultar desse fracionamento.

Em razão das limitações da técnica dos elementos de conexão, em matéria de contratos internacionais, ficou claramente colocada a necessidade de situá-los em perspectiva que possa computar os dados de fato, ou da realidade econômica e social. Impöe-se, assim, passar de análise puramente formal, utilizando as ferramentas clássicas do direito internacional privado, para análise que possa, simultaneamente, computar a pluralidade de aspectos presentes, e as exigências técnicas, bem como situar e reger tais operações em contexto jurídico adequado.

Aldo Frignani (ग) menciona o invito a porsi da una prospettiva che tenga maggiormente conto del dato fattuale, e especifica o conteúdo de tal convite, a tal ponto que a autonomia da vontade das partes não mais seja excludente entre a escolha da tutela de lei nacional de $\mathrm{A}$ ou de $\mathrm{B}$, mas poderá expandir-se até criar regulamento próprio daquela relação, com institutos $\mathrm{e}$ normas jurídicas possivelmente novas ou desconhecidas da totalidade dos sistemas nacionais, e que, como tais, seriam aplicáveis em razão das normas clássicas do direito internacional privado ${ }^{(8)}$.

A distinção entre contratos nacionais e contratos internacionais continua válida: em relação aos primeiros não se poderia justificar, na grande maioria dos casos, a atribuição às partes de uma autonomia tal que pudesse excluir totalmente a regência de qualquer lei nacional; em relação aos últimos, as partes podem, geralmente, escolher a lei aplicável ${ }^{(9)}$. Embora tal distinção resulte, ainda, dos elementos de conexão, segundo os já referidos critérios clássicos do direito internacional privado, é preciso estar consciente do papel crescente, desempenhado pelos práticos, na realidade do comércio internacional, que torna essa noção de contrato internacional suficientemente flexível para poder acolher, como referem Carbone e Luzzatto ${ }^{(10)}$ qualquer rapporto contrattuale non destinato ad esaurirci nei suoi elementi oggettivi o soggettivi, esclusivamente all'interno di un solo ordinamento statuale ${ }^{(11)}$.

A tendência prevalecente seria, antes, de acompanhar a definição do conteúdo internacional de uma relação jurídica, contida em numerosas convenções internacionais, embora não se trate de soluções gerais, mas antes, aplicáveis a cada convenção, para delimitar seu âmbito de aplicação.

Este é o caso, por exemplo, da Convenção de Viena de 1980, sobre a venda internacional de mercadorias, onde o artigo primeiro prevê que o caráter internacional do contrato de venda será avaliado em relação a uma única circunstância, a saber, que no momento da celebração do contrato ${ }^{(12)}$, vendedor e comprador estejam estabelecidos ou sediados em dois Estados diferentes ${ }^{(13)}$ 


\section{Título I - a negociação}

A negociação, antes de uma arte que ciência, não pode -- como todas as demais artes, aliás -- dispensar a técnica, que lhe serve de base e assegura a flexibilidade e o bom nível do desempenho.

Existem, assim, técnicas de negociação de um contrato para as quais devem atentar as partes, da mesma forma como existem técnicas de redação dos contratos e precauções a adotar na escolha da língua do contrato (capítulo II).

Seria, em seguida, conveniente examinar mais de perto o desenrolar das negociações, ou seja, as tratativas, ou pourparlers (capítulo III), atentando para a sua natureza jurídica e o seu papel, e as dificuldades dos contratos internacionais, bem como as conseqüências das tratativas.

\section{Capítulo II - técnicas de negociação e redação de contratos e escolha do idioma}

A negociação de um contrato se desenvolve tendo por escopo a celebração do contrato, como guia os paralelos objetivos das partes e como limitação a regulamentação ou regulamentações jurídicas nacionais ou convencionais, que mais ou menos diretamente serão aplicáveis e influenciarão a formação e a vida do contrato. Mas esse percurso em nada esclarece quanto à formação do contrato, no que se poderia designar como sendo seu processo interno. Embora tendo escopo comum a atingir, embora conservando seus interesses específicos, e as restrições legais externas, tudo isso não explica o procedimento de formação do contrato, que se realiza durante a negociação.

Dentre o grande leque de temas que poderiam ser examinados, seria conveniente destacar três aspectos que podem influenciar profundamente não somente o desenrolar das negociações mas também todo o período de vida do contrato, e o equilibrio da relação entre as partes.

São, justamente, a escolha da técnica de negociação (seção 1), da técnica de redação (seção 2), e da língua do contrato (seção 3) os aspectos sobre os quais seria oportuno chamar a atenção.

\section{seção 1 - técnicas de negociação}

A negociação não é um mecanismo exclusivo dos comerciantes, nem tampouco se pode pretender situar sua descoberta ou invenção no tempo.

Longa digressão histórica seria inútil, considerando que o comércio se confunde com as próprias origens da civilização, e os intercâmbios comerciais foram mola impulsionadora de contato com outras civilizações. Mas é preciso, sobretudo, levar em conta o papel do comércio como fator estimulante não-somente do intercâmbio e circulação de mercadorias e de capitais, mas também de idéias e da própria civilização. Todo intercâmbio comercial normalmente é precedido de negociação, que pode ser complexa ou sumária, segundo o negócio almejado.

A negociação é um diálogo ${ }^{(14)}$. Trata-se de diálogo encetado entre partes que podem se tornar eventuais partes contratantes. As partes devem examinar em 
conjunto sua disponibilidade a vincular-se reciprocamente. O diálogo entabulado servirá para determinar se é viável pretender alcançar acordo de vontades, que possa permitir o estabelecimento de conjunto de regras, de determinar em comum os direitos e obrigações que vão integrar suaș relações.

A natureza e duração da negociação podem variar segundo o negócio almejado. Dentre muitos outros aspectos haverá diferenças substanciais entre a negociação passo a passo ou uma negociação enquadrada na seqüência de um procedimento de licitação.

A pluralidade das técnicas de negociação não exclui a possibilidade de destacar alguns princípios gerais. Michel Dubisson ${ }^{(15)}$ observa que as técnicas de negociação relevent surtout de la psychologie et du bon sens e que existem e são escolhidas em função do local e do momento, da natureza do negócio, da pessoa dos negociadores, e dos eventuais antecedentes nas relações entre as partes ${ }^{(16)}$.

Não obstante a insistência de Dubisson de que a negociação est un art qui ne saurait s'apprendre comme une technique, e que se por um lado elle demande une grande experience, elle suppose également des dispositions naturelles particulieres, nosso autor nos dá alguns conselhos que seria recomendável aplicar durante qualquer negociação ${ }^{(17)}$ :

a. em primeiro lugar, é essencial preparar adequadamente a negociação. Para tanto é preciso antes de mais nada determinar com a maior clareza possível os objetivos essenciais. Isso permitirá ao negociador, qualquer que seja o desenrolar ulterior da negociação, tomar sempre a posição mais adequada. E, igualmente, indispensável ter pleno conhecimento dos papéis que integram o dossier. Seria, ainda, útil ter informações a respeito da psicologia dos negociadores do outro lado, e sobre os objetivos da outra parte. Se não se dispõe de tais informações no momento em que a negociação é encetada, será necessária dedicar esforço todo especial à coleta de tais dados, em tempo útil, no curso desta, a fim de tentar avaliar a margem de manobra dentro da qual opera a outra parte.

b. quando a negociação é encetada, nunca se deve dar à outra parte a impressão de estar apressado para chegar a um acordo. Isso seria um sinal de fraqueza, do qual o outro lado poderia tentar tirar vantagem. Por seu turno, tão logo se obtenha uma concessão da outra parte, é indispensável fazer imediatamente o assentamento de tal concessão, de modo que esta não venha a ser recolocada em discussão mais tarde. Contudo, nem sempre será necessariamente oportuno que tal acordo parcial seja formalizado por escrito. $\mathrm{Na}$ verdade, o pedido, formulado por uma parte, para proceder à redação dos termos de um tal acordo poderia encontrar a recusa da outra parte, vendo aí uma armadilha. Além disso, de modo geral, parece preferível limitar, tanto quanto possível, a remessa de documentos e escritos durante uma negociação, enquanto esta não tiver sido terminada e que não se conheça a extensão completa das concessões que será eventualmente necessário fazer mais tarde. Tais documentos, de fato, cristalizando, no curso da negociação, a manifestação de vontade das partes, constituiriam vínculos, a respeito dos quais seria difícil reabrir o debate. Bastaria, normalmente, assinalar oralmente, mas de modo muito explícito, o ponto de acordo ao qual se chegou no curso da reunião de negociação. 
c. é preciso fazer esforço no sentido de orientar a discussão antes para os pontos essenciais, antes de abordar questões de detalhe. Além disso, convém começar pelos pontos nos quais se acredita seja mais fácil de chegar a um acordo, a fim de criar clima favorável. Se, durante as discussões, tem-se a impressão de enfrentar dificuldade insuperável, seria preferivel não concentrar excessivamente esforços para liquidá-la, sem antes ter discutido o conjunto das questões tidas como essenciais, de modo a poder avaliar, com conhecimento de causa, a importância do impasse. Pelo mesmo motivo, será importante evitar fazer concessões importantes à outra parte, quanto a aspectos relevantes, sem ter previamente passado em revista o conjunto dos demais problemas importantes, a fim de poder medir o alcance da concessão que se estaria disposto a fazer, em relação ao equilíbrio do conjunto do negócio.

d. enfim, é as vezes oportuno saber dramatizar as discussões e romper as negociações quanto a aspecto considerado fundamental, fazendo saber, ao mesmo tempo, de algum modo, imediatamente ou a seguir, que se estaria pronto a retomálas, se a outra parte aceitasse tornar sua posição mais flexível ou modificá-la.

\section{seção 2 - técnicas de redação do contrato}

A técnica de redação do contrato, que será adotada em cada caso, vai ser o reflexo do sistema jurídico no qual está inscrito o contrato.

Para situar de modo estrito a análise nesse campo, haverá diferenças notáveis entre os países da tradição do common law e os países da tradição de civil law.

Nos países do common law, o estilo de redação (drafting style) dos contratos é influenciado pelas técnicas de redação legal (statutes). Pollock ${ }^{(18)}$ observa que o legislador, por ter sido obrigado a se defender de uma interpretação "literal e rígida", por parte dos tribunais, desenvolveu a tendência a formular as leis com grande atenção para os detalhes, onde a Tatbestand se vê diluída em diversas hipóteses que dificilmente poderiam ser qualificadas como abstratas e gerais.

Essa tendência é ainda mais acentuada nos contratos, em razão da ausência de codificações, com suas leis de aplicação necessária, que não podem ser descartadas, mesmo diante da expressão contrária da vontade das partes, ou as leis supletivas, que fornecem quadro geral, cujo papel é o de preencher as lacunas deixadas pelas partes.

As diferenças de approach jurídico sảo tais que, segundo Allan Farnsworth ${ }^{(19)}$ quando um common lawyer vê um contrato redigido com cláusulas bastante breves e privado de definições, ele se vê incomodado com isso; da mesma forma que um civil lawyer, na situação inversa, também se sentirá incomodado, por razões opostas.

Seria, assim, possível distinguir dois grandes sistemas de drafting legal techniques, dos quais um seria aplicável nos países do common law, enquanto o outro seria aplicado nos países do civil law. 
Nos países do common law, o contrato será, normalmente, self-regulatory, ou seja, redigido de modo bastante detalhado, de forma a conter todos os elementos que as partes pudessem considerar como importantes, e todas as hipóteses que poderão acontecer, tendo por escopo assegurar a presença, no contrato, dos instrumentos aptos a resolver todos os eventuais problemas futuros.

Nos países de civil law o contrato se reporta ao conjunto do ordenamento jurídico, que serve de moldura na qual estão colocadas todas as noções de base, e para onde se voltarão as partes na busca das soluções para qualquer hipótese não prevista pelas partes no contrato.

Essa distinção, válida sobretudo para os contratos internos, também tem sido extensamente aplicada para os contratos internacionais, na medida em que cada uma das partes tende a querer aplicar seu estilo de raciocínio e suas técnicas de redação jurídica.

A doutrina insistiu muito a respeito do esforço de desnacionalização dos contratos internacionais, e os profissionais militantes muitas vezes envidaram enormes esforços para escapar aos direitos nacionais das partes contratantes. A extensão da aplicação desse mecanismo dependerá do grau de liberdade que atribui cada sistema jurídico nacional à vontade das partes ${ }^{(20)}$.

As considerações precedentes são válidas sobretudo para os contratos redigidos ad hoc pelas partes. É preciso observar que, no comércio Internacional, os contratos-tipo ou contratos-padrão (contrats-type ou standard agreements) desempenham papel de grande importância. As associações profissionais, as organizações internacionais e seus órgãos especializados muitas vezes oferecem modelos contratuais completos e não-somente as tradicionais cláusulas padronizadas para oferecer às partes contratantes.

Fenômeno curioso, observado por Aldo Frignani (21), é que mesmo os contratos-padrão, oferecidos pelas associações profissionais, refletem, por sua redação e estrutura, a filiação a um ou outro dos sistemas jurídicos.

Os contratos-padrão do ORGALIME, que reúne países europeus em sua maioria filiados à tradição jurídica romano-germânica são breves, concisos e contém regras que não comportam senão um mínimo de generalidades, enquanto os contratos FIDIC, de inspiração inglesa, são longos, muito detalhados e comportam especificações mesmo quanto a hipóteses pouco freqüentes. Por seu turno os contratos-padrão de organizações internacionais tais como a Economic Commission for Europe (ECE) -- Comissão Econômica para a Europa, da ONU, são influenciados, segundo nota Frignani, antes "dallo scopo di delocalizzare il contratto che non dalla funzione suppletiva dei codici" ${ }^{(22)}$.

Normalmente a escolha da técnica de redação do contrato escapa ao controle das partes ou de uma das partes. Aldo Frignani, destaca quatro grupos de elementos que podem explicar as limitações à escolha da técnica de redação do contrato ${ }^{(23)}$ :

a. em determinados setores econômicos (como por exemplo no comércio internacional de commodities), a utilização de fórmulas contratuais é de tal modo difundida, que as partes se acham perfeitamente à vontade para se reportar a estas. 
Mesmo que o comprador não tivesse intenção de utilizar um desses contratospadrão, o vendedor dificilmente estaria disposto a aceitar tal derrogação;

b. algumas vezes grandes empresas multinacionais construíram seus contratos-padrão com dois objetivos precisos: defender seus interesses em relação a seus co-contratantes e assegurar a uniformidade de contratação, para todas as empresas integrantes de um mesmo conglomerado econômico;

c. freqüentemente, a parte contratante mais forte prepara o contrato, e o submete à aprovação da outra parte (mesmo não se tratando de um contrato de adesão, a possibilidade da outra parte questionar ou discutir partes do contrato é muito redurida);

d. o equilibrio entre as partes pode ser encontrado por meio de um contrato-padrão preparado por uma organização internacional (UNCTAD, CEE, etc.) cujo objetivo é justamente tentar levar em conta e estabelecer mediação entre os interesses de ambas as partes.

A escolha da técnica de redação do contrato não é um aspecto isolado. Além dos elementos referidos por Frignani é preciso também levar em conta que a redação do contrato é direta e necessariamente influenciada pela negociação que foi desenvolvida pelas partes, e também pelo idioma no qual será redigido o contrato. Outros elementos (tais como a escolha da lei aplicável, a opção pela arbitragem como modo de solução de controvérsias, ou a determinação do foro competente) podem interferir e ter grande alcance sobre essa decisão.

\section{seção 3 - idioma do contrato}

Estabelecer relações negociais com parceiros estrangeiros requer, muitas vezes, conhecimentos bastante aprofundados de uma língua estrangeira, e da terminologia jurídica desse idioma, que será a ferramenta para permitir a comunicação e a negociação entre as partes de um eventual contrato.

Esse enfoque estritamente pragmático se vê muitas vezes posto em cheque por enfoque de nacionalismo exacerbado, com insistência desprovida de sentido quanto à exigências de uso do vernáculo, como único idioma aceitável ${ }^{(24)}$.

Além desse aspecto sentimental, a questão da escolha da língua do contrato é também dado técnico de importância fundamental, na medida em que a determinação do idioma do contrato pode acarretar igualmente a determinação tanto do direito quanto do foro competente, além de nortear todo o contexto jurídico no qual se insere a relação entre as partes.

A escolha do idioma do contrato muitas vezes é considerada como menos importante do que outros dados. Tal atitude não é aceitável.

Neste passo, ocorrerão, igualmente, diferenças entre uma negociação livre e a negociação que decorre de uma licitação. Essa distinção fica muito próxima dos aspectos já mencionados a propósito da negociação do contrato ${ }^{(25)}$. 
Na maioria dos casos, não havendo imposições prévias quanto à escolha do idioma do contrato, três possibilidades se colocam:

- utilização de diversas línguas, cada uma das quais terá valor oficial, inclusive para fins de interpretação;

utilização de uma língua oficial, ao lado de outra língua, à qual não se confere valor oficial ou de interpretação;

utilização de uma única língua.

A primeira alternativa parece ser a mais perigosa e a menos satisfatória, na medida em que a terminologia jurídica, em cada idioma, terá sentido específico, com termos e conceitos dificilmenete equivalentes. Este pode ser o ponto de partida de profundas divergências entre as diferentes versões de um mesmo contrato, com as graves e imprevisíveis conseqüências que isso pode acarretar.

Mesmo a criação de uma comissão jurídica comum para as diferentes versões do contrato, ou a previsão de submissão de qualquer litígio decorrente do contrato a uma comissão que levasse em conta o conté́do das diferentes versões do contrato podem vir a ser soluções pouco satisfatórias para dirimir controvérsias resultantes de diversidade de interpretação dos direitos e obrigações contratuais, tendo por base as diferentes versões do contrato ${ }^{(26)}$.

A segunda alternativa permite os inconvenientes mencionados no caso de adoção de diferentes línguas. Esta segunda possibilidade pode ser muito útil por razões de conhecimento do conteúdo do contrato, nos casos daqueles que desconhecem a língua oficial do contrato, não-somente nas relações entre as partes, mas também no relacionamento destas com suas respectivas administrações, bancos, companhias de seguros, etc.

A versão não-oficial poderá ser assinada ou não pelas partes, mas de qualquer modo a versão oficial deverá especificar tratar-se da única versão oficial, apta a figurar como fonte para a interpretação do contrato.

A terceira solução muitas vezes é a mais adequada para um contrato internacional. Neste caso não haverá dúvidas a respeito de diversidades de interpretação lingüística, mesmo no caso em que uma única língua constitua a versão oficial do contrato. Mas sempre ocorrerá a mesma indagação que se coloca a respeito da escolha da língua do contrato, quando as partes tiverem a possibilidade de escolher e não houver vínculos diretós com um determinado idioma. No caso de uma das partes se ver imposta língua que lhe é totalmente desconhecida, é preciso que essa parte possa avaliar os eventuais custos ligados a tal escolha lingüística. Não se trata somente de despesas de tradução, mas também de poder contar sempre com jurista suficientemente fluente, familiarizado e com suficiente experiência daquele sistema jurídico estrangeiro para poder avaliar com precisão o peso e as conseqüências que podem resultar de tal escolha, e da adequação da transposição jurídica entre as duas línguas. É também preciso pensar que durante todo o período de execução do contrato haverá quantidade significativa de documentos redigidos na língua oficial do contrato, que será necessário traduzir e conhecer.

Uma ou mais cláusulas regulando a questão da língua do contrato e a utilização dos idiomas nas relações contratuais são indispensáveis em qualquer 
contrato internacional (27). As normas FIDIC, por exemplo, têm cláusula regulando a questão da língua do contrato ${ }^{(28)}$.

Mesmo que a pluralidade dos idiomas seja um fato normal nas relações contratuais internacionais, será sempre necessário estabelecer hierarquia ou, ao menos, clara definição de papéis entre as várias línguas utilizadas pelas partes, especificando seu papel na determinação de direitos e obrigaçōes das partes e na interpretação das cláusulas contratuais ${ }^{(29)}$. Não obstante seus inconvenientes, o dépeçage lingüístico de uma relação contratual pode se mostrar uma alternativa válida e útil, assegurando mais flexibilidade, por exemplo, na correspondência ou outros documentos secundários enviados pelas partes, enquanto os principais documentos contratuais serão redigidos e submetidos à interpretação em língua neutra, ou na língua estrangeira conhecida pelas partes contratantes.

\section{Capítulo III - desenvolvimento da negociação: tratativas}

Após as técnicas de negociação e redạção e a escolha do idioma contratual, convém examinar mais de perto o desenvolvimento da negociação.

As partes entabulam entendimentos ou tratativas (pourparlers). Esse procedimento preliminar pode levar ou não à celebração de um contrato. Mas, vale refletir: qual é a natureza jurídica e qual o papel de tais entendimentos (seção 1)? $O$ contexto internacional da negociação colocará dificuldades específicas a tais entendimentos, as quais deverão ser levadas em conta (seção 2). Finalmente, quais podem ser as conseqüuencias de tais entendimentos (seção 3)?

\section{seção 1 - natureza jurídica e desenvolvimento da negociação}

A expressão do consentimento das partes é o critério para a determinação da formação do contrato, e a distinção entre celebração do contrato (ou contrato definitivo e tratativas) depende quase exclusivamente da expressão recípocra do consentimento das partes. É importante poder determinar se o contrato já foi celebrado, ou se as partes ainda se encontram em estágio pré-contratual. Durante o período das negociações, as partes não estarão vinculadas pelo contrato que tencionam celebrar, e estão preparando, senão na medida em que a negociação exprima o consentimento das partes, mesmo se a expressão desse consentimento não alcança senão aspectos parciais.

O aspecto fundamental dessa distinção é a identificação das categorias comportamentais suscetiveis de engedrar acordo entre as partes. Para que o consentimento exista, é preciso que se dê o encontro de duas manifestações de vontade concordantes. Na medida em que o comportamento das partes não apresente tais características, estaremos, ainda, no domínio das simples tratativas. 
O consentimento se exprime, normalmente, por uma oferta, seguida da respectiva aceitação, feita por um intercâmbio simultâneo de manifestações de vontade, no momento da assinatura do documento contratual. Mas, o momento no qual se exprime o consentimento pode não ser tão claro, nem tão facilmente determinável, sem que seja, tampouco, possível, negar a existência de relações contratuais entre as partes.

Normalmente, a evidência da existência de uma oferta aceita é o suficiente para comprovar a celebração do contrato, mas esta não é, de forma alguma, a prova exclusiva. A existência do consentimento pode, igualmente, ser determinada por outros modos, tais como a produção de documentos relatando a formalização de tais vínculos ${ }^{(30)}$.

A existência de acordo pode, igualmente, ser deduzida do comportamento das partes, sem que se procure identificar oferta e aceitação, mas exprimindo vínculo tácito, que não seria negado pelo comportamento das partes, não obstante a inexistência de consentimento expresso. $O$ simples intercâmbio de mensagens que se prolonga por determinado período de tempo pode caracterizar tanto um simples convite a negociar quanto uma verdadeira negociação.

\section{seção 2 - dificuldades específicas dos contratos internacionais}

A formação do contrato, suas formalidades e conseqüências podëm apresentar dificuldades específicas, em se tratando de contratos internacionais (31) como bem ilustra a existência de convenções internacionais contendo regulamentação desse problema, tais como a Convenção da Haia, de $1^{\mathbf{2}}$ de julho de 1964, sobre a formação dos contratos de venda internacional de objetos móveis corpóreos, ou a Convenção de Viena, de 11 de abril de 1980, sobre os contratos de venda internacional de mercadorias.

No caso de um contrato internacional, a lei aplicável para regular sua formação é determinada pelo sistema de soluções de conflitos de leis no espaço, ou seja, o sistema de direito internacional privado no seio do qual trabalha o juiz (32).

\section{seção 3 - efeitos da negociação}

A discussão que precede a celebração do contrato somente desempenha papel relevante na medida em que possa exprimir a evolução, ou as diferentes etapas da expressão do consentimento das partes, e não pelo debate considerado em si mesmo.

Na prática, a negociação pré-contratual desempenha, muitas vezes, papel fundamental. Isso se explica pela importância e pelas complexidades crescentes dos bens, objeto de intercâmbio, bem como pelos mecanismos jurídicos de sua implementação. O encontro imediato da oferta e da aceitação, já observava Gothot ${ }^{(33)}$ é, freqüentemente, fórmula demasiado simplista.para resolver todos os problemas colocados por tais acordos.

Durante o período pré-contratual, existe clima de tensão que é vivido por todas as partes envolvidas, de dicotomia entre a necessidade de salvaguardar sua liberdade de não contratar, até o momento em que sede o acordo definitivo, e a 
necessidade de garantir sua segurança, no tocante aos fragmentos contratuais já negociados. Cada parceiro terá o cuidado de tentar- salvaguardar sua própria liberdade, ao mesmo tempo em que considerará indispensável garantir sua segurança, com relação às condições negociadas.

Esse conflito entre liberdade e compromisso das partes é analisado por Joanna Schmidt (34), que observa: "o respeito absoluto da liberdade contratual levaria a recusar qualquer intervenção" -- ou efeito -- "jurídica até que o contrato seja celebrado, ficando as partes livres para conduzir a negociação como melhor lhes parecer. A necessidade de segurança exige, por seu turno, a intervenção do direito, de forma a assegurar a harmonização dos interesses colocados frente a frente, em contexto de respeito à lealdade e boa fé. $O$ direito controla, dessa forma, as relações pré-contratuais, garantindo certa deontologia das negociações: os mecanismos da responsabilidade civil delitual são principalmente utilizados para satisfazer tal objetivo, e extrair as conseqüências cabíveis dos comportamentos contratuais faltosos".

\section{Titulo II - vínculos pré-contratuais: carta de intençōes e pré-contrato}

O desenvolvimento da negociação de um contrato pode conduzir a decisões pontuais ou pode se ver limitado por restrições de ordem interna ou externa, tanto como por requisitos que estarão na base das relações contratuais, e que deverão ser levados em conta a seguir.

Dentre os múltiplos mecanismos dos quais podem se servir as partes, as cartas de intenções e os pré-contratos estão entre os mais freqüentemente utilizados.

Embora sejam práticas correntes, as cartas de intenções e os pré-contratos foram bastante negligenciados pela doutrina, persistindo, todavia, grandes incertezas, tanto a respeito de sua definição quanto de seus efeitos jurídicos.

A carta de intenções e o pré-contrato mesmo sendo preliminares em relação a um contrato principal posterior não se confundem com este último. Trata-se, agora, de situar a noção e os aspectos principais da carta de intenções (cap. IV) em relação aos pré-contratos (cap. V).

\section{Capítulo IV - a carta de intenções}

A carta de intenções, já se disse, é aspecto muito importante e bastante negligenciado ${ }^{(35)}$ do fenômeno da formação contratual.

As reflexões da doutrina são pouco numerosas e a prática fez uso das cartas de intenções em situações tão diversificadas ao ponto de tornar a noção bastante vaga ou mesmo incerta.

Seria, assim, conveniente, tentar definição da carta de intenções (seção 1), antes de analisar a noção de pré-contrato em relação à carta de intençōes (seção 2) e, finalmente, os efeitos da carta de intenções (seção 3). 


\section{seção 1 - definição}

A carta de intenções é mecanismo pré-contratual de expressão dos objetivos e da disponibilidade das partes em assumir compromissos no limiar do processo cujo resultado será -- normalmente, em caso.de sucesso das negociações -- a celebração do contrato principal.

A carta de intenções desempenha duplo papel, na medida em que constitui, ao mesmo tempo, um balanço dos pontos já alcançados e um programa de ação para as partes.

Esses dois elementos poderiam ser analisados separadamente: a carta de intenções, enquanto balanço dos pontos já alcançados, sistematiza aspecto muito específico da negociação; enquanto programa de ação, a carta de intenções exprime a expectativa dos resultados da negociação, devendo dar uma base praticamente estável do estado da negociação.

A idéia central da carta de intenções é que as partes, pela assinatura colocada em tal documento, se vinculam em processo de negociação, ou mesmo em contrato de negociação, ou de compromisso de negociar.

A carta de intenções deve fornecer indicações a respeito do dever de negociar, considerado em si mesmo, e exprimir as obrigações das partes, dentre as quais, especialmente, a obrigação de não mais recolocar em discussão os pontos já decididos durante a negociação e inscritos na carta de intenções.

É preciso levar em conta o fato de que o dever de negociar deve ser encarado como obrigação de resultado, e o fato de subtrair-se a tal compromisso pode colocar em jogo a responsabilidade contratual.

\section{seção 2 - pré-contrato e carta de intençōes}

A carta de intenções é um dos mecanismos de formação dos contratos que, normalmente, assinala o término da fase dos entendimentos preliminares, ou tratativas. A carta de intençōes, precedendo o contrato definitivo, tem o mesmo campo de aplicação do pré-contrato.

A definição ideal e teórica da carta de intenções apresenta dificuldades e sempre suscitou controvérsias. Poder-se-ia mesmo, acompanhando o grupo de trabalho de Marcel Fontaine, dizer que não existe conceito bem definido da carta de intenções ${ }^{(36)}$ e que a expressão vem sendo utilizada pelos práticos em hipóteses tão diversificadas, em concorrência, ademais, com outras expressões análogas (tais como accord de principe, protocole d'accord, letter of understanding etc.).

Guy Pevtchin observa que a carta de intenções é conseqüência da complexidade dos projetos ${ }^{(37)}$. Essa complexidade acarreta, obrigatoriamente, a existência de fase pré-contratual as vezes bastante longa, onde concorre a colaboração de diversas empresas, que nem sempre estão agrupadas em consórcio chefiado por um líder. Além de sua duração, o período pré-contratual pode acarretar custos consideráveis: custos de estudos preliminares e deslocamentos de pessoas, salários, etc. A título de exemplo poderiam ser citados os acordos relativos a construção de fábricas prontas para operação (usines clé sur porte), os acordos relativos à prospeç̧ão ou extração de produtos do subsolo terrestre ou marítimo, os 
contratos de fornecimento de matérias-primas a longo prazo, ou a transferência, a licença ou exploração conjunta de tecnologias de ponta ${ }^{(38)}$

A semelhança entre a carta de intenções e o pré-contrato é assinalada por Guy Pevtchin ${ }^{(39)}$, na medida em que, em ambos os casos, trata-se de "délais dans la rédaction des contrats, des autorisations administratives de derniere minute qui manquet, etc. En d'autres termes, on se trouve dans une zone grise et on ne distingue plus clairement si l'on est en présence d'un contrat ou pas".

Da mesma forma que o pré-contrato, observa Mirene Geninet ${ }^{(40)}$, a carta de intenções fixa os elementos do contrato principal, a respeito dos quais as partes estão de acordo, enquanto aguardam a celebração do contrato definitvo, ou as autorizações administrativas necessárias à formação desse contrato.

Poder-se-ia, igualmente, assinalar o papel econômico e financeiro desempenhado pelos pré-contratos: o de permitir às partes contratantes fazê-los valer junto aos bancos, visando a obtenção de financiamento, ou tentar a conquista de um mercado, e a celebração de outros contratos ${ }^{(41)}$.

No campo econômico e financeiro, a analogia é muito nítida entre o papel da carta de intenções e o pré-contrato, enquanto técnicas de formação do contrato definitivo.

No campo jurídico, o papel reconhecido pela prática à carta de intenções é bastante extenso, indo desde a mais elementar sistematização das negociações preliminares até o acordo autorizando o início da execução do contrato principal, antes que este seja celebrado em sua forma definitiva.

O alcance da carta de intenções ultrapassa o do pré-contrato, cuja vocação não comporta a execução parcial do contrato principal, antes de sua conclusão definitiva. A obrigação de sigilo, imposta às partes em razão do pré-contrato, permite deixar a situação em expectativa, o objeto no estado descrito por ocasião do pré-contrato, mas, absolutamente, não se trata jamais de execução das obrigações que resultarão do pré-contrato.

\section{seçăo 3 - efeitos da carta de intençôes}

A carta de intenções exprime a obrigação das partes de levar a bom termo a negociação encetada, segundo a organização para esta prevista, mas é difícil supor que a carta de intenções pudesse obrigar as partes à efetiva celebração do contrato principal.

A carta de intenções, normalmente -- como indica o próprio nomen juris -exprime a intenção das partes quanto à negociação, considerada como um meio de alcançar, mediante condições satisfatórias, a celebração do contrato principal.

A carta de intenções terá, assim, como efeito, a criação de obrigação de discutir as condições de um contrato futuro, cuja natureza e conteúdo foram definidos, por meio da carta de intenções.

Essa obrigação de discutir as condições de um contrato futuro contém duas prestações de natureza diversa: de um lado, uma obrigação de resultado, ou seja, a de entabular a negociação, e por outro lado, uma obrigação de meios, a saber, a de conduzir a negociação com boa fé. 
A obrigação de resultado, decorrente da carta de intenções, ou seja, a obrigação de entabular a negociação não implica, necessariamente, que o contrato principal venha a ser concluído. Não há modo de estipular a obrigação de celebração do contrato inicialmente almejado pelas partes. As partes podem se dar conta, no curso da negociação, que thes é impossivel chegar a um acordo, no tocante às condições do contrato definitivo. Se a obrigação de entabular a negociação foi seriamente respeitada, as partes poderão, validamente, encerrar suas relações, sem que seja cabivel cogitar qualquer tipo de indenização.

A obrigação dos meios, resultante da carta de intenções, diz respeito à boafé na conduta da negociação, e pode ser avaliada por si mesma. As partes ficam, nesse sentido, obrigadas a formular propostas sérias, que devem, por seu turno, ter relação direta e precisa com o objeto e as ordens de grandeza econômicas, colocadas em jogo pelo contrato. Negociar de boa-fé significa, no conjunto, manter atitude ativa e positivamente orientada no sentido da busca de um acordo definitivo.

\section{Capítulo V - o pré-contrato}

O pré-contrato se coloca como preliminar do contrato principal, do qual seria o precursor e o garantidor, durante o desenrolar da negociação.

Para melhor situar o conteúdo da expressão pré-contrato, seria interessante analisá-la em relação à noção de contrato (seção 1), antes de passar em revista algumas noções próximas (seção 2), e, finalmente, examinar a extinção do précontrato (seção 3).

\section{seção 1 - a noção de contrato e o pré-contrato}

O pré-contrato $\varepsilon$ um acordo de vontades contendo promessa sinalagmática de celebrar contrato definitivo, ou o compromisso de o considerar como celebrado, caso o beneficiário do pré-contrato aceite a opcaão contida no contrato preliminar, acarretando, assim, a celebração automática do contrato principal.

O pré-contrato, além do compromisso de celebrar o contrato principal, ou de considerá-lo como celebrado em caso de aceitação da opção, pode, igualmente, conter a expressão do acordo das partes, quanto a determinados elementos que integrarão o contrato definitivo, mesmo sem dispor de todos os elementos necessários à formação do contrato principal.

A análise da noção de contrato deve nos permitir distinguir três categorias: a essência do contrato, a natureza do contrato e dados acidentais do contrato.

A doutrina francesa, por exemplo, dentre os elementos essenciais do contrato de venda, por exemplo, aponta como indispensável a existência de acordo sobre o objeto e o preço, bem como a vontade do proprietário de transferir a propriedade, transferência essa aceita pelo adquirente ${ }^{(42)}$.

Depois dos elementos essenciais (les choses qui sont de l'essence du contrat) Pothier ${ }^{(43)}$ descreve os elementos que são da natureza do contrato (la nature du contrat), distintos dos elementos essenciais, porquanto o contrato pode subsistir sem eles, sendo passíveis de exclusão, por convenção das partes; e distintos, ainda, dos elementos acidentais do contrato (choses accidentelles du contrat), que não sendo 
ligados à natureza deste, só se encontram, em determinado caso, em razão de cláusula específica, acrescentada ao contrato pelas partes.

Essas três categorias podem nos permitir situar o pré-contrato em relação à noção de contrato. A essência do contrato deverá ser determinada pelo précontrato. Assim, se no exemplo do contrato de compra e venda, falta o acordo quanto à transferência da propriedade, não mais se trata de venda e compra, mas de locação; daí a utilidade e necessidade de acordo das partes quanto à tipologia contratual, acordo esse distinto do acordo quanto ao objeto e ao preço. Além disso, para que o contrato projetado se torne o contrato principal, é preciso que exista manifestação de concordância das partes, para que o acordo definitivo produza a plenitude de seus efeitos ${ }^{(44)}$. Dentre os elementos relativos à natureza do contrato, sempre no exemplo do contrato de venda e compra, é preciso que as partes organizem a perfeição consensual, solene ou real, quer se trate de contrato definitivo consensual, solene ou real. Enquanto as partes não tiverem procedido a tal organização, a formação do contrato principal não está determinada.

Organizando a perfeição da venda sob forma consensual, solene ou real, as partes podem descartar a presunção legal, segundo a qual, em caso de silêncio dos contratantes, o acordo quanto ao objeto e ao preço acarreta a perfeição do contrato principal. A perfeição da venda, elemento da natureza do contrato, pode já estar ou não estipulada no pré-contrato, sem ter efeitos sobre a formação do contrato principal.

Os elementos acidentais, por seu turno, acrescentados pelas partes, nos termos de determinada cláusula específica, tais como o prazo acordado para pagamento do preço, ou a faculdade de proceder ao pagamento do preço em prestações sucessivas, não têm efeito sobre a formação do contrato principal. A venda e compra estaria igualmente celebrada, mesmo que as partes não tivessem acordado tais detalhes.

\section{seção 2 - pré-contrato e noçōes próximas}

Para melhor situar a noção de pré-contrato, seria conveniente relacioná-la com as noções próximas, e considerar especificamente os estudos técnicos preliminares, a punctação (punctation) e os contratos-quadro.

\section{a. pré-contrato e os estudos técnicos}

A importância econômica dos bens objeto do contrato e a complexidade dos instrumentos contratuais normalmente determinarão a necessidade de estudos técnicos e de contratos preliminares. Esses dois mecanismos, não obstante sua aproximação temporal (sendo, ambos, utilizados em momentos similares) e seu papel acessório, em relação ao contrato principal, não devem ser confundidos. Convém, ora, precisar a noção de estudo técnico preliminar.

Um estudo técnico destina-se a examinar a concepşão da obra que será objeto do contrato principal. No momento do estudo técnico trata-se de averiguar se a operação planejada é factível de ponto de vista tecnológico, e de determinar o modus faciendi, de forma a assegurar a compatibilidade entre os aspectos objetivos 
pretendidos pelo cliente, as exigências e/ou técnicas impostas pelo ordenamento jurídico local e a rentabilidade do projeto.

O contrato de estudo técnico preliminar não se confunde com os précontratos, embora ambos se situem na fase que precede a celebração do contrato principal.

\section{b. o pré-contrato e a punctação}

A punctação (punctation) ou formação sucessiva do contrato ${ }^{(45)}$ é outra noção próxima, mas que não deve, tampouco, ser confundida com o pré-contrato.

Punctação é termo que pode ser empregado para designar ${ }^{(46)}$ a formação do contrato em etapas sucessivas, ou formação pontual, mas, o sentido mais estrito do termo designa $\mathrm{o}$ instrumento redigido pelas partes para fixar pontos da negociação sobre os quais já foi alcançado acordo.

A punctação designaria, assim, o acordo sobre determinados elementos do contrato principal.

A punctação pode abordar elementos essenciais ou acessórios do contrato, mas não se confunde com o contrato principal nem tampouco com o pré-contrato.

A punctação é expediente destinado a fixar os elementos já estabelecidos do contrato, resumindo, assim, as partes os frutos das negociações preliminares, fixando por escrito seus principais elementos. Trata-se de obrigação de não voltar à discussảo de tópicos já acordados pelas partes.

\section{c. o pré-contrato e o contrato-quadro}

O contrato-quadro é acordo entre diferentes partes a respeito de determinados elementos fundamentais que terão papel de contrato de aplicação para as encomendas futuras entre fornecedor e distribuidor.

J. M. Mousseron (47) observa que o contrato-quadro é acordo visando definir as principais regras segundo as quais serão regidos acordos a serem sumariamente celebrados no futuro, ou seja, contrats d'application d'exécution, para os quais simples pedidos ou faturas simplificadas serão emitidos.

Assim, percebe-se, tampouco o contrato-quadro se confunde com o précontrato.

\section{seção 3 - extinção do pré-contrato}

No momento em que é feita a promessa de contrato no pré-contrato, a oferta do contrato principal ainda não foi inteiramente formulada, considerando que segundo os termos de tal promessa é que as partes se organizarão para atender as prestações contratuais. A seqüência das negociações poderá acarretar duas conseqüências: ou a celebração do contrato principal, ou a caducidade e inexecução do pré-contrato. 
A celebração do contrato principal é o resultado da promessa de contratar, formulada no pré-contrato. O contrato definitivo, observa Irineu Strenger ${ }^{(48)}$ é o ato pelo qual as partes se comprometem a aceitar determinadas obrigações, exprimindo a natureza jurídica dos laços que as vincularão.

A expressão do acordo das partes, desde o pré-contrato até o contrato definitivo será, sempre, acompanhada por efeitos jurídicos, e suas diferenças serão antes diferenças de grau, de limite e de eficácia, do que diferenças de natureza ${ }^{(49)}$.

$O$ contrato definitivo confere estabilidade à expressão do acordo das partes, refletindo a confiança recíproca, no momento da contratação, bem como a expectativa de solidez e de intenção de boa-fé nas relações entre as partes.

A caducidade do pré-contrato pode resultar de diversos eventos: seja a morte de uma das partes, ou desligamento de determinada pessoa dos quadros de uma empresa, no caso de pré-contrato celebrado intuitu personae, ou em razão de causas de caducidade resultantes da própria natureza do contrato, desejada pelas partes e regulada por cláusulas claras e precisas. Dentre as modalidades de caducidade, a mais freqüênte é a fixação, no pré-contrato, de prazo, durante o qual ficam vinculadas as partes.

A inexecução do pré-contrato vincula a responsabilidade do promitente. Dentre as obrigações resultantes do pré-contrato, figura a obrigação de sigilo (que se divide em conservação material e conservação jurídica da coisa) e as obrigações relativas à conclusão do contrato definitivo ${ }^{(50)}$.

$O$ inadimplemento da obrigação de conservação material do objeto vincula a responsabilidade do promitente, podendo acarretar a condenação a reparar o prejuízo sofrido pelo beneficiário, seja mediante o pagamento de indenização, seja mediante reparação em espécie.

Mesmo que o objeto do contrato definitivo seja materialmente conservado, o pré-contrato pode não ser executado se uma das partes se recusar a celebrar o contrato definitivo, ou se tal celebração tornou-se impossível, em razão da violação, pelo proprietário, da obrigação de conservação jurídica do objeto.

A conclusão do contrato principal pode se tornar impossivel tanto em razão da aquisição, por um terceiro, de direitos concorrentes sobre o objeto do contrato definitivo, ou em razão de violação da obrigação de conservação jurídica do objeto, no estado em que se encontrava no momento da celebração do pré-contrato, geralmente isenta de ônus e integrando a propriedade do promitente.

Em suma, o inadimplemento do pré-contrato pode ter causas múltiplas. Tal inadimplemento poderá acarretar sanções, caso vincule a responsabilidade do promitente.

\section{Segunda Parte - A formação do contrato}

A negociação do contrato e os vínculos pré-contratuais, foram o objeto das páginas precedentes. Partindo da análise anterior, podemos agora enfocar a formação do contrato.

A formação do contrato está direta e necessariamente ligada à existência de uma oferta e de sua aceitação (título I), mas ocorrem diversidades entre sistemas, porquanto, em direito inglês, por exemplo, é preciso poder, igualmente, caracterizar 
a intenção das partes quanto ao estabelecimento de relações jurídicas (a intention to create legal relations) e a ocorrência de válida consideration (aspectos, por seu turno, examinados no título II).

\section{título I - oferta e aceitação}

A oferta e a aceitação são os elementos fundamentais para a formação do contrato, por meio dos quais se exprime o acordo das partes.

Oferta e aceitação são duas noções clássicas, extensa e cuidadosamente bem estudadas. Nesse sentido, não se trata de retomá-las sob a óptica do direito civil clássico, mas sobretudo, de confrontá-la com as exigências colocadas pelos contratos internacionais.

\section{Capítulo VI - oferta}

A formulação de uma oferta marca uma nova etapa no processo contratual, constituindo o marco inicial decisivo para a formação do contrato, que pode vir a ser completado pela aceitação.

Nesse sentido é importante comparar a oferta e o estabelecimento de negociação entre as partes, e de distinguir bem as duas noções (seção 1), antes de analisar os elementos necessários à existência da oferta (seção 2), e finalmente, os efeitos da oferta, especialmente a possibilidade e as conseqüências de sua revogação (seção 3).

\section{seção 1 - oferta e tratativas}

A oferta, por sua natureza e efeitos, se distingue do simples estabelecimento de negociação, ou entrée en pourparlers, na medida em que a oferta encerra, em si mesma, o objetivo e a possibilidade de alcançar a celebração do contrato.

Existe nítida gradação da firmeza na expressão da intenção de contratar ${ }^{(51)}$. Essa escala de graus de firmeza terá como expressão mais completa e precisa a oferta, permitindo imediata aceitação por parte do destinatário. A firmeza da vontade de contratar implica no abandono, por parte do autor da oferta, ao destinatário, da faculdade de formar o contrato, mediante simples aceitação das condições oferecidas. Qualquer restrição imposta por seu autor a tal manifestação desqualificaria a oferta.

O autor da oferta que acarretará a formação do contrato não é necessariamente quem tomou a iniciativa de formular a primeira proposta, mesmo que esta tenha sido suficientemente firme e precisa para poder constituir verdadeiramente uma oferta. A oferta que formará o contrato é aquela que encontrará a aceitação pura e simples da outra parte. Ou seja, o autor da oferta constitutiva do contrato é quem que formula aquela oferta que encontrará aceitação por parte de seu destinatário, sem reservas nem contra-propostas. 


\section{seção 2 - existência da oferta e seus elementos}

A formulação de uma oferta é etapa decisiva na expressão do consentimento. Nesse sentido, embora não seja indispensável que a oferta contenha todos os elementos do contrato futuro, ela deve, necessariamente, ser suficientemente precisa para que possa conter todos os elementos essenciais do contrato. A formação do contrato deve poder resultar da simples aceitação por parte do destinatário da oferta, sem que seja necessário acrescentar outras precisões.

Elemento essencial para poder caracterizar a vinculação das partes seria a formulação de oferta, cuja aceitação das condições pelo destinatário estaria apta a formar o contrato.

A oferta, contudo, não poderá contribuir para a formação do contrato, nem vincular, como tal, a responsabilidade de seu autor, que com a condição de ser precisa, firme e inequívoa, de forma a exprimir verdadeiro compromisso. Não estando revestida de tais características não seria uma oferta; mas simples convite a entabular negociação (invitation à entrer en pourparlers) ou tomada de preços ou licitação (appel d'offres ou bid).

Breve exame desses elementos forneceria parâmetros para melhor situar a formulação de uma oferta, no curso de uma negociação.

Dizer que a oferta deve ser precisa não implica em dizer que esta deverá necessariamente se apresentar sob a forma de um projeto completo de contrato, mas é indispensável que ela fixe os elementos essenciais do contrato proposto.

O grau de precisão necessário depende, em grande medida, da natureza do contrato. Em contrato de venda, retomando o exemplo clássico, deverá ser mencionada a coisa vendida e seu preço. Por seu turno, uma oferta de serviços pode dar lugar ao nascimento de um contrato, mesmo sem comportar indicações de preço, caso seja habitual que este venha a ser determinado mais tarde, como em muitos casos de honorários profissionais.

De qualquer forma, as reservas somente afetarão de modo útil a oferta caso sejam expressas ou, se forem tácitas, caso correspondam aos usos ou à natureza da convenção. $E$, de fato, indispensável que o destinatário da oferta possa tomar conhecimento das reservas, para que essas mesmas reservas possam validamente ser invocadas posteriormente.

A oferta deve, ainda, ser clara e inequívoca, de modo a vincular seu autor, e permitir a formação do contrato. Seus elementos devem ser formulados com precisão. Ofertas simultâneas e contraditórias não permitem percepção clara da vontade de seu autor.

\section{seção 3 - efeitos da oferta: possibilidade e consequiências da revogaçåo}

O efeito principal da oferta é a formação do contrato, mediante a coincidência com a aceitação formulada pelo destinatário da oferta. Caso o autor da oferta pretenda, nesse momento, se retratar, e retirar a proposta, haveria inexecução do contrato, suscetível de acarretar a execução forçada e de vincular a responsabilidade contratual. 
Esse efeito principal da oferta é inseparável da aceitação e das condições nas quais se dá a concordância necessária à formação do contrato.

A oferta, em si mesma, tem valor jurídico próprio. Mesmo antes de sua aceitação, constitui manifestação voluntária -- e cabe indagar em que medida esse fato voluntário permanece sob o controle da vontade de seu autor. Dizer isso implica especificar em quais condições pode ocorrer a revogação da oferta e determinar o tempo durante o qual a oferta conservará sua eficácia.

A doutrina clássica francesa, segundo J. Ghestin ${ }^{(52)}$ estimava que a oferta poderia ser livremente revogada. O contrato somente sendo formado pela concordância da vontade das partes, faria com que a oferta, antes de sua aceitação, não tivesse qualquer força obrigatória. Mesmo admitindo esse princípio, a jurisprudência impôs-lhe importantes restrições, em torno das quais foi feito grande esforço de justificação quanto aos fundamentos jurídicos. Já os autores contemporâneos, observa o mesmo autor, se, por um lado, concordam em afastar a explicação deduzida de um pré-contrato, preferem, alguns, pleitear a existência de vínculo unilateral, enquanto outros falam em responsabilidade delitual.

Sem retomar longo e tortuoso debate a respeito do tema, é preciso, contudo, ter presente o fato de que, pode ser que exista um verdadeiro pré-contrato, ou um vínculo unilateral, ou ainda omissão, acarretando a responsabilidade do autor da oferta.

A existência e a manutenção da oferta pode ser objeto de verdadeiro acordo. Segundo 'venerando' Arrêt emanado da Cour de Colmar (53),

"une offre peut être considerée comme obligatoire pour celui qui la formule, même avant acceptation de celui auquel elle est destinée, des lors qu'il résulte d'un accord expres ou tacite, mais indiscutable, qu'elle a été formulée pour être maintenue pendant un délai déterminé".

\section{Capítulo VII - aceitação}

A aceitação é a resposta à oferta, e é com a formulação da aceitação que se completa a formação do contrato. Mas, o que, exatamente, quer dizer 'aceitação'? Qual é a noção de aceitação (seção 1)? Aceitação é, essencialmente, expressão de concordância, mas a simples ausência de recusa, ou seja o silêncio, pode este caracterizar a aceitação (seção 2)? Vale, ainda, examinar, em seguida, os efeitos da aceitação para a celebração do contrato (seção 3 ).

\section{seção 1 - noção de aceitação}

A formação de vínculos entre as partes, dos quais resultará a formação do contrato, exige a concordância entre a oferta e a aceitação. Não é indispensável que a manifestação da vontade abranja a totalidade dos aspectos da oferta, mas é necessário que o acordo das partes alcance efetivamente os elementos considerados pelas partes como essenciais.

Com o intuito de precisar quais sejam os elementos da noção de aceitação, pode-se distinguir, acompanhando J. Ghestin ${ }^{(54)}$, os elementos objetivamente essenciais e os elementos considerados pelas partes como essenciais. 
Os elementos objetivamente essenciais são aqueles que acarretam a determinação das prestações, mutuamente respaldadas em contrapartidas. Dependem tais elementos da operação jurídica que tende a formar o contrato. No caso, sempre lembrado, de compra e venda, os elementos objetivamente essenciais são constituídos pela determinação do objeto da prestação e seu preço.

Além dos elementos objetivamente essenciais, as partes sempre podem convencionar que a formação do contrato fique subordinada a elementos, que por sua natureza, teriam caráter acessório, mas que são elevados, pelas partes, naquela negociação em curso, à determinação, por exemplo, da data ou do local de entrega, da data de pagamento, ou mesmo da realização de evento exterior ao contrato.

A aceitação comportando reservas significa uma contra-oferta, que constituiria, a rigor, recusa da oferta original, comportando formulação de nova oferta, que ficaria sujeita a nova aceitação.

Tendo abordado a noção de aceitação, seria, agora, oportuno examinar, dentre as modalidades possíveis, o papel do silêncio, como manifestação de aceitação. Esta deve, normalmente, ser feita, em alguns casos, com a ausência de manifestação.

\section{seção 2 - o silêncio vale aceitação?}

A regra geral orienta-se no sentido de que o silêncio não é equivalente à aceitação de uma oferta. $\mathrm{O}$ mais freqüente é não existirem fórmulas ou modalidades especificas, exceto se tais formalidades forem impostas por lei, ou resultarem de prática habitual, consagrada por usos e costumes ou convenção das partes ${ }^{(55)}$.

Nem os direitos nacionais, nem tampouco o direito convencional formulam exigências a respeito da forma da aceitação, sendo, esta, inclusive, passível de comprovação por testemunhas.

É possível imaginar que o silêncio desempenhe papel como modalidade de expressão da aceitação, quando as partes tivessem previamente estipulado que a celebração futura do contrato far-se-ia pelo silêncio de uma das partes.

O silêncio, considerado como modalidade de aceitação, é viável nos casos em que tivesse ocorrido sucessão de vínculos anteriores entre as partes contratantes ${ }^{(57)}$. Nessa continuidade de laços contratuais, o silêncio de uma das partes, diante da nova proposição formulada pela outra, poderia vir a ser admitido como equivalente da aceitação ${ }^{(58)}$.

Normalmente, durante ou ao término das negociações entre as partes, nos casos em que não tivesse ocorrido qualquer contrato anterior, o dever de exprimir claramente a aceitação será, normalmente, indispensável, de forma a assegurar a formação do contrato.

\section{seção 3 - efeitos da aceitação e celebração do contrato}

A expressão da aceitação é o momento fundamental para a formação do contrato. E somente a partir da aceitação que tem pleno cabimento a pretensão à existência de vínculos entre as partes, clara e inequivocamente caracterizando a existência de contrato, e das relações entre partes contratantes, com a nítida 
distinção entre o período pré-contratual e o período contratual, e conseqüentes diversidades de regime daí resultantes.

A aceitação, da qual decorre a celebração do contrato, reveste-se de grande importância, sobretudo em matéria de contratos internacionais, não-somente porque a celebração do contrato assinala o divisor de águas e a transição entre a fase pré-contratual e a fase contratual, e somente a partir desse momento poderão integrar o conteúdo do contrato as modificações a respeito das quais tenham as partes podido alcançar novo acordo, mas especialmente, porque o momento da celebração permite determinar, igualmente, o local de celebração do contrato, não obstante a evolução dos meios técnicos de transmissão tenda a crescente 'deslocalização' da formação contratual.

A determinação do local de celebração do contrato -- não obstante o célebre exemplo de Henri Batiffol, a respeito do empreendedor libanês e de seu parceiro celebrando contrato durante ascenção em ski-lift de Saint Moritz, como tipificação de irrelevância do local de celebração do contrato -- pode ser significativa tanto na determinação da lei aplicável quanto do foro competente. Tal determinação será, normalmente, simples, quando estiverem as partes simultaneamente presentes no momento da contratação, mas faz-se menos simples, na maioria dos casos, em que se trata de contratação inter absentes. Os sistemas jurídicos nacionais podem estipular que, em determinados casos, as modalidades escolhidas pelas partes para a celebração do contrato podem ser equiparados à presença efetiva das partes, mas tais dificuldades ainda não foram totalmente superadas ${ }^{(59)}$.

Nesse campo existem dois modelos principais, acolhidos pelos vários sistemas nacionais, tendo como fonte, respectivamente, em um caso, o direito romano e no outro, o modelo adotado pelo common law.

Em diversos direitos nacionais de inspiração romana, a norma ${ }^{(60)}$ é de que a celebração do contrato somente ocorre no momento em que o autor da oferta toma ciência da aceitação de sua oferta pelo destinatário desta.

Nos países do common law, bem como nos países germânicos, a conclusão do contrato tem lugar no momento da expedição (segundo a assim chamada mail box rule).

Em caso de revogação da aceitação da oferta, mas, ainda mais freqüentemente, em caso de revogação da aceitação, essa diversidade de regimes nacionais pode ter conseqüências muito sérias, sobretudo porque a grande maioria dos contratos internacionais são, em grande medida, contratos de autor da oferta, de saber até que momento pode ser feita a revogação desta, e para o destinatário, de determinar até que momento será possível a revogação da aceitação. Tais situações tornam-se tanto mais consideráveis em contexto de inflação acelerada ${ }^{(61)}$, de instabilidade política ou de riscos graves de mudanças substanciais ${ }^{(62)}$.

A busca de critério uniforme, para fazer face a tais diversidades nacionais sempre foi e continua a ser ponto central dos esforços de unificação nas convenções internacionais em matéria de direito do comércio internacional.

O único domínio, no qual foram alcançados resultados concretos é o da venda de objetos móveis corpóreos, mesmo sem ter podido alcançar acordo quanto a adoção de um ou outro dos referidos modelos nacionais de formação contratual, porquanto os representantes de países que adotam a mail box rule podem ter 
conferido bastante importância ao conhecimento efetivo do conteúdo da aceitação, por parte do autor da oferta, mas nem por isso impuseram a divisão entre o momento da celebração do contrato, ligado à expedição da aceitação e a eficácia do contrato, que, por seu turno, está ligada à efetiva tomada de conhecimento da aceitação pelo autor da oferta ${ }^{(63)}$.

Cada um dos modelos fez concessões ao outro, sem renunciar totalmente a seus próprios princípios: o modelo baseado na mail box rule acolheu a idéia da necessidade da tomada de conhecimento do autor da oferta, para assegurar a eficácia da aceitação e o modelo de fonte romana, por seu turno, acatou a idéia de que o contrato pode ser considerado como tendo sido celebrado no momento em que procede o conhecimento da aceitação ${ }^{(64)}$.

A Convenção de Viena sobre a venda internacional de mercadorias prevê, especificamente, em seu art. 23 , que o momento da celebração do contrato está vinculado à eficácia da aceitação.

A eficácia da aceitação, por seu turno, é regulada pelo art. 18 , em três aspectos principais:

recusa de considerar o silêncio como aceitação;

a aceitação se dá mediante declaração, no momento em que esta chega ao autor da oferta;

possibilidade de que a aceitação seja considerada como decorrente da prática de determinado ato (como, por exemplo, a expedição da mercadoria ou o pagamento) que terá efeitos no momento em que for praticado ${ }^{(65)}$.

No tocante a outros aspectos não regulados pelas convenções internacionais será necessário recorrer às normas nacionais de direito internacional privado, concernentes à determinação da lei aplicável ${ }^{(66)}$.

Título II - intention to create legal relations e a consideration no direito inglês

Os dois elementos essenciais na formação do contrato completam-se, em direito inglês, com dois outros: a intention to create legal relations e a consideration.

O objeto deste título é a de apresentar as principais características destes dois elementos, em dois capítulos (no capítulo VIII, a intention to create legal relations e, no capítulo $\mathrm{LX}$, a consideration).

\section{Capítulo VIII - intention to create legal relations}

Contracts must not be the sports of an idle hour, mere matters of pleasantry and badinage, never intended by the parties to have any serious effect whatever.

Lord Stowell (1811) ${ }^{(67)}$

No direito inglês, em matéria contratual (law of contract), o fenômeno do acordo de vontades das partes deve se manifestar conjuntamente com dois outros elementos, para que ocorra a formação do contrato. Esses dois elementos são a consideration ${ }^{(68)}$ e a intention to create legal relations. 
Esta última, a intention to create legal relations, ou intenção de criar vínculos contratuais, que se poderia igualmente tentar enquadrar sob a expressão animus contrahendi, trata-se de esforço de determinar em que medida, além da ocorrência dos elementos característicos da oferta e aceitação, apoiados pela consideration, é necessário que as partes tenham realmente tido a intenção de criar relação jurídica mutuamente vinculante.

Os casos, nos quais a existência de contrato poderá ser negada em razão da ausência da intention to create legal relations podem ser divididos em dois grupos: os contratos não-comerciais (ou domestic agreements) (seção 1) e os contratos comerciais (seção 2).

Seria, ainda, interessante examinar a crítica de Willinston, segundo o qual a noção de intention to create legal relations seria estranha e inadaptada ao common law (seção 3).

\section{seção 1 - contratos nāo-comerciais}

Em matéria de contratos não-comerciais ou domestic agreements, a presença ou ausência de intention to create legal relations será avaliada segundo a interpretação que seria dada por um juiz da linguagem escolhida pelas partes e das circunstâncias nas quais se enquadram os acontecimentos.

Lord Denning, em seu The Discipline of Law ${ }^{(69)}$, com a habitual verve e brilho, analisando o fenômeno da 'construction of contracts', no enfoque da matéria dos 'family arrangements and presumed intent', observa a necessidade de perquirir a intenção das partes:

Apart from the contract proper, the doctrine has proved to be of much help in deciding 'family arrangements'. In these cases husband and wife - mother and daughter, or the like - often make loose arrangements for the future. But as a separation or a divorce - and the Court has to decide what is to be done. (...)

In all these cases of contracts or family arrangements, I ask the question: In the case of an unforesseen turn of events, is the Court justified in asking itself: What is the fair and just solution of the problem? or, is this altogether too vague and uncertain? Does it leave too much to the discretion of the Judge?

A vida familiar contém numerosos acordos que nunca se poderia cogitar transformar em objeto de um processo, mas, tampouco, a vida familiar exclui a formação de relações contratuais, e as circunstâncias podem indicar a intenção de uma das partes vincular-se perante a outra.

Cheshire, Fifoot e Furmston, em seu clássico Law of Contract (70), analisam, separadamente, os acordos entre cônjuges (agreements between husband and wife), os acordos entre pais e filhos (agreements between parent and child), e os demais contratos não-comerciais, reunidos em terceiro grupo (other domestic agreements), ressaltando que é preciso analisar cada caso em seus elementos, para poder determinar a possibilidade de efeitos jurídicos. Decisões antagônicas evidenciam claramente tais contrastes. 


\section{No caso MERRIT v. MERRIT ${ }^{(71)}$ :}

O marido abandonou o lar conjungal. O imóvel estava em nome de ambos os cônjuges e onerado por hipoteca. Posteriormente alcançaram acordo, segundo o qual o marido faria pagamento mensal de 40 libras esterlinas à mulher, e que todos os pagamentos relativos à hipoteca incumbiriam à mulher. Esta exigiu que o acordo fosse feito por escrito e o marido escreveu e assinou um papel declarando:

"in consideration of the fact that you will pay all charges in connection with the house (...) until such time as the mortgage repayment has been completed I will agree to transfer the property in your sole ownership".

Depois de efetuar o pagamento do montante total devido em razão da hipoteca, a mulher se viu diante da recusa do marido quanto à transferência da propriedade do imóvel em seu nome.

A Court of Appeal entendeu que as partes tinham tido a intenção d criar relação jưrídica e que uma ação executória por inadimplemento contratual seria aceitável (72).

\section{No caso BALFOUR v. BALFOUR (73):}

O querelado era funcionário do serviço público civil, transferido ao Ceilão (atual Sri Lanka). Sua mulher alegou que durante periodo de férias, passado na Inglaterra, no momento em que ficou evidenciada a impossibilidade desta em acompanhá-lo, em razão de saúde frágil, seu marido lhe teria prometido fazer remessas mensais de 30 libras esterlinas, para custeio de suas despesas, durante o período em que estivessem obrigados a viver separados. A mulher promoveu ação executória por inadimplemento desse contrato.

A Court of Appeal decidiu que as partes não tinham tido em mente a criação de relações jurídicas, e que a ação era destituída de fundamento. $O$ juiz Atkin observou que, não obstante a ocorrência da consideration, era evidente que as partes não tinham pretendido à formação de um contrato ${ }^{(74)}$ :

"It is necessary to remember that there are agreements between parties wich do not result in contracts within the meaning of that term in our law. The ordinary exemple is where two parties agree to take a walk together or where there is an offer and an acceptance of hospitality.

Nobody would suggest in ordinary circunstances that those agreements result in wath we know as a contract, and one fo the most usual forms of agreement wich does not constitute a contract appears to me to be the arrangements wich are made between husband and wife ... To my mind those agreements, or many of them, do not result in contracts at all ... even though there may be wath as between other parties would constitute consideration ... They are not contracts because the parties did not intend that they should be attended by legal consequences."

No caso PETTIT v. PETTTT ${ }^{(75)}$ diversos membros da Câmara dos Lordes, muito embora acatando o princípio enunciado no caso BALFOUR v. BALFOUR estimaram que a decisão sobre os fatos estava muito próxima dessa tendência. Observaram, igualmente, que muitas vezes, um acordo entre cônjuges, mesmo não sendo tido como vinculante entre as partes, nem por isso seria destituído de conseqüências jurídicas. Segundo Lord DIPLOCK ${ }^{(76)}$ : 
"many of the ordinary domestic agreements between man and wife do not possess the legal characteristics of a contract. So long as they do not give rise to any - choice in action, for neither party intended that non-performance of their mutual promises should be the subject of sanctions in any court (see BALFOUR $v$. $B A L F O U R$ ). But this is relevant to non-performance only. If spouses do perform their mutual promises, the fact that they could not have been compelled to do so while the promises were executory cannot deprive the acts done by them of all legal consequences upon proprietary rights; for these are within the field of the law of property rather thanof the law of contract. It would, in my view, be erroneous to extend the presumption accepted in BALFOUR v. BALFOUR that mutual promises between man and wife in relation to their domestic arrangements are prima facie not intended by either to be legally enforceable to a presumption of a common intention of both spouses that no legal consequences should flow from acts done by them in performance of mutual promises, with respect to the acquisition, improvement or addition to real personal property - for this would be to intend what is impossible in law."

Os contratos entre pais e filhos podem apresentar problemas semelhantes aos contratos entre cônjuges. Exemplo ilustrativo disso é o caso JONES v. PADAVATTON $^{(77)}$ :

A Sra. JONES em Trinidad. Sua filha trabalhava na Embaixada da Índia em Washington. Ela tinha sido casada, e tivera um filho, mas já estava divorciada naquele momento. A Sra. JONES queria convencer sua filha a ir para a Inglaterra e tornar-se barrister, e prontificou-se a fazer remessas mensais para custear-lhe as despesas, durante o tempo de preparação para os exames. A filha, após muita hesitação, decidiu-se a ir para a Inglaterra em 1962. Em 1964 a Sra. JONES adquiriu uma casa em Londres. Sua filha vivia com a criança em uma parte da casa; sendo o restante ocupado por locatários. Os alugueres cobriam parte das despesas da casa e da manutenção de ambos. Em 1967, a Sra. JONES e sua filha se desentenderam e a Sra. JONES pediu a posse da casa. Por ocasião da audiência, a fillha somente concluira parte dos exames de ordem.

Foi necessário conceber a existência de dois acordos. Segundo o primeiro, a filha concordara em sair de Washington e se preparar para os exames em Londres, e sua mãe se prontificara a enviar-lhe mensalmente quantia certa em dinheiro. Nos termos do segundo acordo, a mãe permitira a ocupação da casa por ela adquirida, e cujos alugueres serviam ao custeio das despesas de manutenção da filha. Em cada um dos acordos havia uma troca de promessas, mas em nenhum dos casos se fizera qualquer apontamento por escrito, ou especificação de prazos. $O$ aspecto a ser determinado era saber se em cada um dos casos as partes tinham tido a intenção de criar relações jurídicas.

O juiz da Country Court rejeitou o pedido da mãe de retomada da posse do imóvel, mas a decisão de primeira instância foi reformada pela Court of Appeal. Os juízes Danckwerts e Fenton Atkinson declararam que em nenhum dos acordos tinha havido intenção de criar relações jurídicas:

"The present case is one of those family arrangements wich depend on the good faith of the promises wich are made and are not intented to be rigid, binding arrangements" (78) 
O juiz Salmon concordou em receber a apelação mas por razões diversas. Segundo ele, o primeiro acordo era um contrato cuja duração deveria se estender por prazo razoável para permitir à filha completar seus exames. Os cinco anos transcorridos desde então estariam, assim, terminados. O segundo acordo, relativo à posse da casa, era de tal forma impreciso e omisso na regulamentação de tantos aspectos que não se poderia pretender interpretá-lo como um contrato. Nada, quer no acordo, ou nas provas fornecidas, poderia fazer supor que a mãe tivesse intenção de renunciar a seu direito de propriedade, ou a possibilidade de retomar a posse do imóvel, no momento em que assim o desejasse. A filha não passava de simples licensee ${ }^{(79)}$

Existe, ainda, terceiro grupo de contratos não-comerciais, distintos daqueles dois primeiros grupos, de contratos entre cônjuges e contratos entre pais e filhos.

No caso SIMPKINS v. PAYS ${ }^{(80)}$ :

A querelada possuia uma casa na qual vivia com $X$, sua neta e o querelante, na qualidade de locatário (paying boarder). Os três participavam conjuntamente, todas as semanas, de competição organizada por um jornal. As fichas eram apresentadas em nome da querelada, mas não havia regras determinadas, regulando o pagamento das despesas postais e de outros encargos. Uma semana, a ficha da querelada foi a vencedora, recebendo prêmio de 750 libras esterlinas no concurso. $O$ querelante pleiteou o recebimento de um terço dessa quantia, mas a querelada recusou-se a fazê-lo, alegando que ele não tivera a intenção de estabelecer relações jurídicas, e que tudo não passava de uma aventura entre amigos.

O juiz Sellers julgou a questão favoravelmente ao autor, embora reconhecendo que:

"there are many family associations where some sort of rough and ready statement is made wich would not establish a contract"

Mas, no caso, entendeu o magistrado ter ocorrido

mutuality in the arrangements between the parties, tratando-se, assim, de uma empreitada comum na qual cada uma das partes contribuíra, na expectativa de compartilhar qualquer resultado que viesse a ser alcançado.

\section{seção 2 - contratos comerciais}

Nos contratos comerciais, em direito inglês, diversamente dos contratos não-comerciais, existe presunção de que as partes tinham intenção de vincular-se e formar o contrato. Mas tal presunção pode ser refutada ${ }^{(81)}$. Alguns exemplos podem ser ilustrativos:

É bastante freqüente fazer publicidade de mercadoria, exagerando suas qualidades e eficácia, além de promessas mais ou menos vagas, de compensação em caso de insatisfação. Se o autor decide fazer aquisição da mercadoria em razão de tais características e promessas, descobrindo, logo a seguir não terem estas qualquer fundamento, e iniciar ação por inadimplemento contratual, o pólo passivo poderá tentar argumentar a inexistência de intenção de criar relações jurídicas, e que somente o mais ingênuo dos consumidores poderia pensar de outro modo. Os tribunais foram confrontados com tal questão, e a Court of Appeal, no caso 
CARLILL v. CARBOLIC SMOKE BALL CO., em $1893{ }^{(82)}$, reconheceu a existência de vínculo jurídico entre as partes.

As partes podem celebrar acordo em matéria comercial, ou outras transações que normalmente seriam reguladas por contrato, declarando que não havia qualquer intenção de criar relações jurídicas. Se tal declaração for feita, ela seria aceitável perante um Tribunal -- como seria igualmente aceitável qualquer outra expressão da intenção clara e destituída de equívocos, manifestada pelas partes.

Exemplo célebre é o caso ROSE AND FRANK v. CROMPTON ${ }^{(83)}$, no qual as partes tinham feito figurar uma honorable pledge clause no texto do contrato, segundo a qual as partes declaravam que o documento não acarretava conseqüências jurídicas e que não havia qualquer obrigação de fazer encomendas ou de aceitar as encomendas porventura feitas, ou ainda de cumprir as cláusulas do contrato.

Em razão de rescisão sem aviso prévio, o autor decidiu acionar seu cocontratante por perdas e danos e não fornecimento de mercadorias já encomendadas. A análise da sentença prolatada no caso, deve levar em conta dois aspectos: a declaração da existência do contrato, e o não fornecimento de mercadorias já encomendadas.

$O$ autor queria ver reconhecido pelo Tribunal, o inadimplemento do contrato, em razão do documento escrito, segundo o qual a outra parte assegurava ao autor direito de distribuição exclusivo. A Court of Appeal não reconheceu a existência de contrato, em razão da declaração feita pelas partes ${ }^{(84)}$. O juiz Scrutton declarou:

It is quite possible for the parties to come to an agreement by accepting a proposal with the result that the agreement does not give rise to legal relations. The reason of this is that the parties do not intend that their agreement shall give rise to legal relations, this intention may be implied from the subject matter of the agreement, but it may also be expressed by the parties. In social and family relations, such an intention is readily implied, while in business matters, the opposite result would ordinarily follow. But I can see no reason why even in business matters, the parties should not intended to rely on each others good faith and honour, with the accompanying necessity of expressing themselves so precisely that outsiders may have no difficulty in understanding what they mean.

O autor, por outro lado, também pleiteara ressarcimento por perdas e danos pelas encomendas feitas anteriormente à rescisão do contrato. Nesse aspecto, o autor obteve o reconhecimento de sua pretensão. Na medida em que cada encomenda era feita e aceita, isso constituía um contrato novo e independente, cuja existência foi deduzida pelo Tribunal sem qualquer referência ao 'memorandum' original, como declarou Lord Phillimore ${ }^{(85)}$ :

According to the course of business between the parties wich is narrated in the unenforceable agreement, goods were ordered from time to time, shipped, received and paid for, under an established system; but, the agreement being unenforceable, there was no obligation on the American Company to order goods or upon the English Companies to accept an order. Any actual transaction between the parties, however, 
gave raise to the ordinary legal rights; for the fact that it was not of obligation to do the transaction do not divest the transaction when doneof its ordinary legal significance.

Palavras inseridas por uma das partes em determinado acordo e destinadasa ou utilizadas mais tarde para excluir conseqüências jurídicas podem ser ambíguas. Em tal caso, o ônus da comprovação de tal intenção incumbe à parte que invoca tal circunstância (86).

Acordos industriais e sindicais também suscitaram a questão da existência ou não da intenção de estabelecer tais vínculos. Bom exemplo disso é o caso da FORD MOTOR CO. LTD. v. AMALGAMATED UNION OF ENGINEERING AND FOUNDRY WORKERS ${ }^{(87)}$ no qual a oferta, a aceitação e a consideration estavam presentes. A questão era saber se tinha havido intenção de estabelecer relações. $O$ juiz Lane entendeu que não:

Agreements such as these, composed largely of optimistic aspirations, presenting grave practical problems of enforcement and reached against a backgroundof opinion adverse to enforceability, are in my judgment not contracts in the legal sense and are not enforceable at law, without clear and express provisions making them amenable tolegalaction, they remain in the realm of undertaking binding in honour (88).

Não obstante a importância dessa decisão, a evolução do direito encaminhou-se para solução diversa, como se pode depreender da análise das seções aplicáveis do Industrial Relations Act, 1971, e do Trade Union and Labor Relations Act, $1974^{(89)}$.

\section{seção 3 - crítica de Willinston}

A intention to create legal relations constituiria o elemento volitivo suplementar, o animus contrahendi, que deve estar presente, além do acordo de vontade das partes e da considerantion.

Essa tripartição dos elementos cosntitutivos do contrato tem aceitação corrente na Inglaterra, não obstante as controvérsias que o tema levanta, como referido. Nos Estados Unidos, contudo, esse elemento volitivo encontra contestação. Dentre os críticos da intention to create legal relations, como um dos elementos de formação e determinação da existência do contrato, se coloca o Prof. Willinston, seguido por outros juristas.

Segundo Willinston ${ }^{(90)}$, o elemento intencional ou volitivo, como elemento indispensável à formação do contrato seria estranho e estaria inadaptado às exigências do common law. A noção de intenção somente teria surgido no common law durante o século XIX, em razão de influências teóricas provenientes do continente europeu, e somente teria utilidade nos sistemas que não contém como controle representado pelo elemento da consideration, para a determinação das fronteiras de um contrato:

The common law does not require any positive intention to create a legal obligation as an element of contract (...) $A$ deliberate promise seriously made is enforced irrespective of the promisor's views regarding his legal liability (91) básicos $(92)$.

Os comentários de Willinston podem ser reduzidos a três enunciados 
- if reasonable people would assume that there was no intention in the parties to be bound, there is no contract;

- if the parties expressly declare or clearly indicate their rejection of contractual obligations, the law accepts and implements their intention;

- mere social engagements, if accompanied by the requisite technicalities, such as consideration may be enforced as contracts (93)

\section{Capítulo IX - a consideration}

O direito inglês, em matéria contratual, exige não-somente a existência da oferta e da aceitação, mas também a consideration para caracterizar a formação do contrato.

Não se trata de retomar, aqui, longa evolução, abrangendo séculos de história, mas, tão-somente, de esboçar os elementos fundamentais (seção 1), antes de passarmos a uma definição da consideration (seção 2) para, em seguida, analisar seu papel (seção 3).

\section{seção 1- elementos fundamentais}

A bipartição entre oferta e aceitação como condições da formação do contrato, que prevalece nos sistemas jurídicos contemporâneos de inspiração romana, se vê substituída por uma tripartição no direito inglês: ao binômio ofertaaceitação acrescente-se a consideration, como elemento indispensável para a vida do contrato ${ }^{(94)}$.

Isso significa que a promessa de fazer ou não fazer determinada prestação somente será eficaz se tal promessa estiver fundamentada na consideration, que se trate do compromisso da outra parte de dar, fazer ou não fazer alguma coisa em contrapartida.

Para compreender a consideration é preciso situar a noção no contexto do direito inglês, e no quadro de evolução histórica no qual este se inscreve ${ }^{(95)}$.

Para poder pleitear perante as Cortes reais, e beneficiar-se do exercício de sua jurisdição, não se exigia somente a comprovação do compromisso assumido entre as partes, e de seu inadimplemento; era preciso, ainda, mostrar que esse compromisso se inscrevia em bargain entre as partes, ou seja, que em troca do compromisso assumido havia uma contrapartida.

$\mathrm{O}$ inadimplemento do compromisso não constituía somente desrespeito à palavra dada, mas também representava deceit, ou seja atuação fraudulenta e lesiva. Justamente este elemento poderia justificar o pedido de intervenção das Cortes reais, para dirimir a controvérsia.

A contrapartida dada ao vínculo, seja o pagamento de preço ou seja sob outra forma é justamente a consideration.

A doutrina da consideration foi sendo estruturada já durante o século XVII mas foi somente à partir do caso RANN v. HUGHES (96) que seus contornos foram definitivamente delimitados, pois até então seus limites eram bastante imprecisos, sofrendo variações resultantes de jurisprudência divergente. A regra então 
estabelecida era a de que somente seriam sancionáveis pela ação de assumpsit os vínculos resultantes de uma bargain.

O direito inglês em matéria contratual, segundo René David Pugsley (97), não foi obra de canonistas, buscando levar à perfeição o legado dos jurisconsultos romanos, subordinado-o aos princípios da moral cristã. Os juízes ds Cortes reais eram processualistas: eles se colocaram na questão de saber em quais casos seria conveniente que as Cortes reais interviessem em assuntos que, em princípio, se inscreviam na órbita de interesse dos particulares. $O$ adágio pacta sunt servanda pode ser excelente para as jurisdições mercantes, mas seria insensato pretender que o sancionassem os Juízes de sua Majestade. A existência ou inexistência de consideration no vínculo contratual invocado pelo autor constituirá, nessas condições, o critério permitindo distinguir quais acordos são sancionáveis e quais não o são perante as Cortes reais ${ }^{(98)}$.

De ponto de vista estritamente prático ${ }^{(99)}$, vale frisar que as Cortes reais não tencionaram ir além. Aceitando como critério do vínculo juridicamente obrigatório a existência de consideration, os Tribunais satisfizeram as necessidades do comércio, e, ao mesmo tempo, evitaram, conforme era seu desejo, qualquer confusão entre direito e moral. $\mathrm{O}$ direito inglês dos contratos pode parecer, assim, ter fundamento diverso do nosso. Trata-se de direito essencialmente comercial e não civil, um direito econômico, não preceito moral transplantado para terreno jurídico; os vínculos assumidos, as promessas feitas (promises) somente são sancionáveis na medida em que integram operação de intercâmbio, uma bargain. Em caso contrário, a ação de assumpsit não os sanciona e tornou-se duvidoso, na era moderna, que, nesses casos, se pudesse falar em contrato.

Este é o princípio: a doutrina inglesa da consideration visa fornecer criterium que permita determinar quais acordos de vontade são obrigatórios, e quais acordos não o são, segundo o common law. Para que um acordo seja juridicamente obrigatório, e seu inadimplemento seja passível de sanção, é indispensável que aquele que o invoca tenha dado uma consideration. O querelado, em caso contrário, dispõe de hábil meio de defesa, tecnicamente conhecido sob o nome de plea in confession and avoidance, pelo qual reconhece ter assumido um compromisso (confession), mas pleitea que esse compromisso seja destituído de valor jurídico (avoidance) $^{(100)}$.

\section{seção 2 - definição}

A consideration, segundo a fórmula de Sir Frederick Pollock (101) exprimindo a posição da Câmara dos Lordes, em $1915^{(102)}$, no caso DUNLOP v'. SELFRIDGE ${ }^{(103)}$, poderia ser definida como sendo:

an act of forbearance of one party, or the promise thereof, is the price for wich the promise of the other is bought and the promise thus given for value is enforceable.

$\mathrm{Na}$ determinação da existência ou não de consideration será, assim, sempre necessário ter em mente o elemento sinalagmático, a ocorrência de contraprestação, dada ou prometida em troca desse compromisso. 
A consideration é elemento que se integra ao momento da formação do contrato. A determinação da presença ou ausência de consideration deve levar em conta o momento de formação do contrato.

A consideration é elemento indispensável à formação do contrato, que se soma à oferta e à aceitação. Em alguns casos, contudo, a consideration se coloca em paralelo à oferta e à aceitação ${ }^{(104)}$. Dóis exemplos podem ilustrar isso:

no caso HART v. MILLS (105) um comerciante de vinhos envia a seu cliente uma seleção de vinhos. O cliente conserva algumas garrafas e devolve as demais. Existe contrato no que se refere às garrafas por ele conservadas. A remessa das garrafas caracterizou, nesse caso, tanto a oferta (tender) quanto a consideration;

- no caso CARLILL v. CARBOLIC SMOKE BALL Co. ${ }^{(106)}$, já referido, existe, da mesma forma, consideration : os problemas causados à Sra. CARLILL pelo tratamento, fazem com que coincidam, e sejam simultâneas, a aceitação e a consideration.

Seria, ainda, conveniente distinguir a executory consideration e a executed consideration.

Ocorre executory consideration se, no momento da celebração, o contrato faz nascer obrigações incumbentes a ambas as partes. A executory consideration, que confere caráter jurídico à obrigação, é a promessa feita pelo co-contratante. A contra prestação ainda não implementada, no momento da formação do contrato: ela é superveniente, e deverá ser dada mais tarde (ou seja, é executory).

A executed consideration, por sua vez, está presente no momento em que a contraprestação prevista é implementada pelo co-contratante, no momento da formação do contrato.

\section{seçäo 3 - papel da consideration}

A idéia básica que respalda a doutrina da consideration (107) é bastante simples e parece muito sensata: não é a totalidade dos compromissos assumidos por uma pessoa que pode ser passível de sanção jurídica ou execução em juízo. $O$ elemento da consideration teve, ainda, outros méritos, porquanto permitiu delimitar noção geral da operação de intercâmbio, da bargain, e qualquer contrato que mereça tal classificação é sancionável pela mesma ação de assumpsit, e sujeito a regime semelhante.

A consideration é elemento sobremodo característico, que reflete com precisão o espírito do direito inglês. $\mathrm{O}$ direito inglês não confere à expressão da vontade, per se, efeitos jurídicos, mas somente na medida em que esta vise a realização de uma bargain: somente são reconhecidos como revestidos de caráter juridicamente obrigatório os vínculos (promises) que comportem a contrapartida de uma valuable consideration.

\section{Conclusão}

A negociação e a formação do contrato são aspectos fundamentais de qualquer relação jurídica. Esses dois aspectos dizem respeito, sobretudo, às etapas preliminares da vida do contrato, mas não devem ser negligenciados, na medida em 
que, durante o desenrolar da negociação, as manifestações das partes podem gerar vínculos, cuja existência e alcance jurídicos por não serem conhecidos, nem por isso são menos carregados de consequiências.

As exigências específicas do comércio internacional trouxeram elementos adicionais de complexidade à negociação e formação dos contratos, na medida em que a diversidade de sistemas jurídicos, a diversidade lingüística e a diversidade cultural colocam barreiras dificilmente superáveis. Mesmo as convenções internacionais em matéria de venda enfrentam tais inconvenientes e nem sempre foram capazes de resolvê-los.

Não obstante a presença e a continuidade das diferenças nacionais e das dúvidas a respeito da possibilidade de alcançar regulamentação uniforme universalmente aplicável, há, apesar de tudo, aspecto extremamente positivo: é o interesse crescente pelo estudo dessas questões, seja no campo do direito internacional privado e do direito do comércio internacional, ou do direito comparado. Verossimilmente todos esses esforços de reflexão poderão levar, se não a transformações profundas, ao menos a melhor conhecimento dos diferentes regimes nacionais, em matéria de negociação e formação de contratos, e particularmente, dos contratos internacionais.

Melhor conhecimento das especificidades locais e das diferenças nacionais pode vir a ser o melhor caminho para progressivamente chegar a superá-las.

\section{Notas}

1. A respeito da infernal parafernália dos contratos financeiros internacionais vale referir bibliografia em separado e análise específica, e.g. Contratos financeiros internacionais (no prelo) em co-autoria com J. Renato C. Freire.

2. A extensão da bibliografia especializada em matéria de arbitragem comercial internacional torna temerária qualquer tentativa de tratamento exaustivo do tema. Não deixo de referir, contudo, trabalho recentemente republicado, de qualidade excepcional, representando insider's view inestimável: International Chamber of Commerce Arbitration, by W. Laurence CRAIG, William W. PARK e Jan PAULSSON (prèfaces by Sir Michael KERR and Pierre BELLET, New YorkParis, Oceana Publ. Inc.-ICC Publ. S.A., 2nd. edition, 1990)

3. Exemplos recentes de esforços nesse sentido são, i.a., dois excelentes seminários promovidos pela $\mathrm{CCI}$, em Paris, versando: Formation des contrats et responsabilité pré-contractuelle (XI reunião anual do Institute of International Business Law and Practice, Paris, 13-14 nov. 1989, dedicando especial atenção ao étude de droit comparé des regles nationales de formation des contrats et de la responsabilité pré-contractuelle) bem como o Séminaire de formation sur la négociation, la rédaction et l'exécution des contrats internationaux (do mesmo IIBLP, com part. PNUD, Paris, 1 e $4-7$ dez. 1989) (doravante referidos Sem. CCI: FCRPC. e Sem. CCI: NRECI) 
4. Rodolfo SACCO, Introduzione al diritto comparato (Torino, G. Giappichelli Editore, seconda edizione, 6. ristampa, 1980, pp. 51 ss.). V. tb. Eric AGOSTINI, Droit comparé (Paris, PUF, 1988).

5. Rodolfo SACCO (op. cit., loc. cit.) aceitação?

6. Sobre o papel do silêncio v. tb. a seção 2 do cap. VII o silêncio vale como

7. Aldo FRIGNANI et al., Il diritto del commercio internazionale (Milano, Ipsoa Informatica, 1986, pp. 43 ss.)

8. Aldo Frignani (op. cit., loc. cit.).

9. Henry LESGUILLONS em seu Contrats internationaux (Paris, Lamy, 1986- ) analisa diversos ordenamentos jurídicos nacionais em matéria de autonomia da vontade das partes em matéria contratual (Deuxieme division, "Le droit applicable", esp. section II, sous-ssections I a XIII, pars. 63 a 157).

10. S. CARBONE e R. LUZZATTO, I contratti del commercio internazionale (in Trattato di diritto privato, sob a coordenação de Pietro RESCIGNO, Torino, UTET, vol. XI, 1984).

11. CARBONE - LUZZATTO (op. cit., p. 117).

12. A respeito da formação do contrato e o regime previsto pela Conv. de Viena, v., i.a., Sem. CCI: FCRPC Session I.10 "formation of contracts and precontractual liability under the Vienna Convention on international sale of goods" $\mathrm{e}$ Sem. CII: NRECI Section 5 "presentation of the Vienna Convention".

13. V., a respeito, Henry LESGUILLONS, Contrats internationaux (op. cit,, 4eme. division, "La vente internationale", passim).

14. Sobre a teoria e prática da negociação bibliotecas inteiras foram escritas. Estudos norte-americanos sobre o tema tem alcançado repercussão que ultrapassa o âmbito normal de difusão no meio jurídico, tornando-se sucessos de vendas, tais como Getting to YES - Negotiating Agreement without giving in by Roger FISHER and William URY, with Bruce PATTON editor (orig. publ. Houghton Mifflin Co. 1981, reprint, New York, Viking Penguin, 1983), observando: "Negotiation is a fact of life. (...) People differ, and they use negotiation to handle their differences. Whether in business, government or the family, people reach most decisions through negotiation." Esse livrinho 'the national bestseller' reúne anos de trabalho no âmbito do Harvard Negotiation Project.

15. Michel DUBISSON, La négociation des marchés internationaux (Paris, FEDUCI-Ed. du Moniteur, 1982, pp. 54/55). 
16. Michel DUBISSON (op. cit., loc. cit.).

17. Michel DUBISSON (idem, ibidem).

18. POLLOCK, Essays in Jurisprudence and Ethics (1882, p.85).

19. Allan FARNSWORTH, The Convention on the International Sale of Goods from the Perspective of the Common Law Countries (conferência pronunciada em Paris, em novembro de 1986).

20. Henry LESGUILLONS, Contrats intermationaux (a respeito do já referido exame bastante detalhado dos sistemas nacionais. em matéria de autonomia da vontade). 44/45)

21. Aldo FRIGNANI, $n$ diritto del commercio internazionale (op. cit., pp.

22. Aldo FRIGNANI (op. cit., loc. cit.).

23. Aldo FRIGNANI (op. cit., p. 46).

24. Tal atitude, muitas vezes atribuída a países sub- ou em vias de desenvolvimento, não é exclusiva de tais países, onde se poderia tentar explicá-la em razão da ausência de tradiçōes políticas ou de inexperiência em negócios internacionais. Nesse sentido, e.g., vide, na França a lei de 31 de dezembro de 1975, ou na Bélgica, o decreto de 21 de junho de 1978, não obstante os 'similares nacionais': desde o Código Comercial, art. 125, estipulando serem "inadmissíveis, nos juízos do comércio, quaisquer escritos comerciais de obrigações contraídas em território brasileiro que não forem exarados no idioma do Império, salvo sendo eștrangeiros todos os contraentes, e neste caso deverão ser apresentados competentemente traduzidos na língua nacional", passando pelo Código Civil, art. 140, "os escritos de obrigação redigidos em língua estrangeira, serão para ter efeitos legais no país, vertidos em português", além do Código de processo civil, arts. 151, I e 157, e a Lei 6015/73, LRP, art. 148 caput e par. único.

25. Vide, supra, seção 1.

26. Para boa análise da questão da harmonização em âmbito intracomunitário v. WJ. Ganshof VAN DER MEERSCH et al., L'hamonisation dans les Communoutés (Bruxelles, U.L.B. - I.E.E., Enseignement Complémentaire nouvelle série, vol. 2, 1968). V., tb., La formation du contrat - harmonisation du droit des affaires dans les pays du Marché Commun (Paris, 1976, pp. 12ss.). 
27. Aldo FRIGNANI (Il diritto del commercio internazionale, op. cit., pp. 103/107) observa:

un contratto con esecuzione all'estero non e tecnicamente compiuto senon contiene una clausola sull'uso delle lingue e non quale sia quella ufficiale: ed inoltre si puo solo raccomandare agli operatori di pretendere quale strumento contrattuale l'inglese od il francese o comunque una lingua a loro conosciuta".

28. A norma FIDIC em matéria de idioma:

art. 5.1. There shall be stated in part II of these conditions: drawn up (...)

a. the language or the languages in witch the contract documents shall be

(...) if the said documents are written in more than one language, the language according to witch the contract is to be construed and interpreted shall also be designated in part II, being therein designated the 'ruling language'.

29. Segundo Aldo FRIGNANI (op. cit., p. 106):

la presenza di una pluralita di lingue regolamnti diverse parti del contratto $e$ una situazione normale nella contrattualistica internazionale. Infatti le condizioni generali $e$ particolari potranno ben essere in lingua locale, mentre tutta parte squisitamente tecnica potrd essere in altra lingua tecnicamente piu ricca e precisa. Si tratta ovviamente di definire bene la gerarchia delle fonti e le prevalenze delle singole parti perche la struttura contrattuale possa effetivamente operare senza ostacoli derivati da conflitti interni. A questo punto appare chiaro che fin dall'inizio delle negoziazioni le parti dovranno aver deciso qual e la lingua da adottare anche la stesura del contratto.

30. A exigência de apresentar comprovação por escrito na existência de contrato cujo valor é superior a $5.000 \mathrm{FRF}$ (cinco mil francos franceses) estipulada pelo art. 1341 do Cód. Civil Francês foi consideravelmente abrandada, em sua aplicação, pela jurisprudência. Entre nós dispositivos semelhantes estão contidos no Código Comercial, art. 123 e Código Civil, art. 141. O 'caput' desse dispositivo da lei civil, teve sua redação alterada pela Lei $1.768 / 52$, e, posteriormente, mais uma vez, pelo art. 401 do Código de Processo Civil. Não obstante o preceito legal limitar a validade de contratos não escritos ao décuplo do maior salário mínimo vigente no País, ao tempo da celebração do contrato, a jurisprudência vem conferindo maior amplitude quanto aos efeitos pretéritos do contrato, por exemplo, na locação de serviços e corretagem, bem como em contratos agrários, conforme disposto no Decreto 59.566/66 admitindo prova exclusivamente testemunhal.

31. Como sempre, é oportuno o ensinamento de Pierre LALIVE, no seu "Sur une notion du contrat intemational" (in Multum non multa - hommage d Kurt LIPSTEIN, org. por Peter FEUERSTEIN e Clive PARRY, Heidelberg-Karlsruche, C.F. Muller Jurist. Verlag, 1980). 
32. O juiz francês procederá à análise da formação do contrato internacional sob a regência da lei de autonomia, ou seja, o sistema jurídico em relação ao qual se localizam as relações das partes. A lei francesa será aplicável para determinar a formação de um contrato internacional quando as negociações apresentarem elemento de conexão principal (lien de rattachement principal) com o ordenamento jurídico francês. Vale referir, a respeito, o excelente estudo e compilação de jurisprudência de Bertrand ANCEL e Yves LEQUETTE, Grands arrêts de la jurisprudence française de droit international privé (préf. de Henri BATIFFOL, Paris, Sirey, 1987), esp. pp. 70, 169 ss. e 336 sobre o caráter internacional do contrato e as conseqüências em matéria contratual.

33. J. GOTHOT, Les pourparlers contractuaels (in la reconnaissance du phenomene contractuel, Commission droit et vie des affaires, Liege, 1971, p. 21).

34. Joanna SCHMIIT, Négociation et conclusion de contrats (Paris, Dalloz, 1982, pp. 6/7).

35. Algumas honrosas exceções a tal silêncio, vide: Guy PEVTCHIN, $\mathrm{La}$ lettre d'intention (DPCI, 1979, pp. 52 ss.) e o grupo de trabalho coordenado por Marcel FONTAINE, Les letters d'intention (DPCI, 1977, pp. 99 ss.).

36. Marcel FONTAINE et al, Les lettres d'intention (Groupe de travail, DPCI, 1977, p. 99).

37. Guy PEVTCHIN, La lettre d'intention (DPCI, 1979, p. 50).

38. Na prática brasileira, tais situações foram sobremodo freqüentes na atuação de agrupamentos de empresas independentes para a construção de projetos hidrelétricos.

39. Guy PEVTCHIN (idem, ibidem).

40. Mirene GENINET, na série de artigos intitulada Théorie générale des avant contrats en droit privé, suite, "Les petites affiches", n. 98, 15 aout 1986, p. 9), observa: "la lettre d'intention fixe les éléments du contrat principal, sur lesquels les parties se sont entendues en attendant la conclusion du contrat définitif ou les autorisations administratives nécessaires d̀ la formation de ce contrat".

41. Tais casos congregam, normalmente, os contratos comerciais e contratos financeiros, utilizando financiamentos internacionais, via EXIMBANK ou outras instituições, como forma de assegurar o fornecimento de equipamentos, peças e acessórios produzidos naquele país, formando pacote que inclui desde os estudos de viabilidade e projetos preliminares, até a instalação e assistência técnica, passando por treinamento de pessoal, etc, estendendo-se por anos, ou mesmo décadas, e envolvendo cifras respeitáveis. 
42. Vide, a respeito, em direito francês, com pitoresca propriedade POTHIER, Traité de obligations, Premiere partie, chapitre I "De ce qui appartient d̀ l'essence des obligations" (esp. pars. 7.2 e 8.3); ou, igualmente, com árida precisão, e enfoque mais moderno, embora menos ilustrativo, J. GHESTIN, Le contrat - Traité de droit civil (Paris, LGDJ, 1980).

43. POTHIER (op. cit., loc. cit.).

44. Mirene GENINET, Théorie générale des avant contrats en droit privé ('Les petites affiches', n. 91, 30 juillet 1986, pp. 30/38).

45. A. RIEG, La punctation - contribution a l'étude de la formation successive du contrat (in Etudes offertes d Alfred JAUFFRET, 1974, pp. 593 ss.).

46. A. RIEG (art. cit., loc. cit.).

47. J. M. MOUSSERON, La durée dans la formation du contrat (in Études offertes à Alfred JAUFFRET, op. cit., pp. 515 ss.).

48. I. STRENGER, Contratos internacionais do comércio (São Paulo, Ed. RT, 1986, Seg. parte 'formação dos contratos internacionais do comércio', cap. X 'decisão').

49. Antonio Junqueira de AZEVEDO, faz análise brilhante da formação do negócio jurídico e de seus diferentes planos de exame, no execelente estudo Negócio juridico - existência, validade e eficácia (São Paulo, 1974).

50. Mirene GENINET, Théorie générale des avant contrats en droit privé (suite, Les petites affiches, n. 108, 8 sept. 1986, pp. 8 ss.).

51. Joanna SCHMIDT, no seu Négociation et conclusion de contrats (Paris, Dalloz, 1982, pp.22/23) observa:

Une personne peut souhaiter la négociation d'un contrat sans avoir la volonté de le conclure immédiatement. La pratique recours alors, fréquemment, à la technique de la 'lettre d'intention', dont la dénomination indique qu'elle est, géneralement, destinée à informer le partenaire de l'intention d'envisager la possibilité de conchure. Les letters d'intention donnent lieu d des difficiles problèmes d'interprétation et de qualification; elles sont, parfois, considérées comme contenant une offre.

Dans d'autres cas, l'initiateur des pourparlers envisage la conclusion du contrat avec un degré supplémentaire de fermeté, qui se manifeste par la formulation d'un 'appel d'offres'.

L'auteur n'entend pas susciter l'acceptation, mais, au contraire, des offres relatives au contrat qu'il envisage de conclure. L'appel d'offres ne comporte pas d'énoncé précis des conditions du contrait projeté, mais fixe un cdre à la négociation qui sera complété par les offres effectivement formulées (ce cadre est fréquemment présenté sous la forme d'un cahier de charges). 
Dans la mesure où de tels actes n'expriment qu'une intention et non une volonté ferme, ils ne peuvent être qualifiés d'offres.

Cette solution peut être appliquée d̀ toutes les demandes de renseignements, de tarifs, de conditions de contrat. De manière générale on est en présence d'un appel d'offres ou invitation à entrer en pourparlers lorsque l'auteur indique clairement qu'il souhaite susciter des offres. Les réponses d̀ une telle invitation seront, éventuellement, des offres que le proposant initial aura la possibilite d'accepter ou auxquelles il répondra par une contre-offre. 161 ss.)

52. J. GHESTIN, Le contrat (in Traité de droit civil, Paris, LGDJ, 1980, pp.

53. COUR DE COLMAR, Arrêt du 4 février 1936 (DH 1936, p. 187).

54. J. GHESTIN, Le contrat (op. cit., pp. 172/173).

55. Rudolf B. SCHLESSINGER et al., Formation of Contracts - $A$ study of the common core of legal systems, Dobbs Ferry-London, Oceana Publ. Inc.-Stevens \& Sons, 1968, 2 vols.).

56. Art. 3 LUFC; art. 11 CVIM.

57. V. infra, cap. VII.

58. O silêncio, em determinadas ocasiōes, pode produzir efeitos jurídicos. A propósito, v. CCI Sent. 3344/81 (Clunet, 1982, p. 978).

59. V., a respeito, BECKER, International telex contracts (JWTL, 1983, p. 514); CARLINI, La formazione del contratto tra persone lontane (in Aspetto della revisione delle comparazione tra common law e civil law nel quadro di un diritto comune, RTDPC, 1984, p. 114); L. O. BAPTISTA, Aspectos juridicos das transferências eletrônicas internacionais de fundos (tese de livre docência, apresentada à FADUSP, São Paulo, 1986).

60. Dois exemplos podem ilustrar a aplicação do modelo: os Códigos Civis brasileiro, regula a matéria nos seus arts. 1082 a 1087, e o italiano, no seu art. 1326 dispõe:

il contratto e concluso nel momento in cui chi a fatto la proposta ha conoscenza dell'accettazione dell'altra parte. L'accettazione deve giungere al proponente nel termine stabilito $o$ in quello ordinariamente necessario secondo la natura dell'affare e secondo gi usi. $I l$ proponente puo ritenere efficace l'accettazione tardiva, purche ne dia immediatamente avviso all'altra parte. Quallora il proponente richieda per l'accettazione una forma determinata, l'accettazione non ha effetto se è data in forma diversa. Un'accettazione non conforme alla proposta equivale a nuova proposta. 
61. O contexto inflacionário e seus efeitos sobre a moeda e a estabilidade e equilíbrio das relações jurídicas constituem capítulo fascinante e problemático, já bastante estudado, mas sempre renovado. Para enfoque da matéria nos Tribunais ingleses vale referir 'The Rt Hon' Lord DENNING, Master of the Rolls, no seu The Discipline of Law (London, Butterworsths, 1979), analisando 'inflation and presumed intent' (part I, cap. 4, section 12, pp. 48/50). Para bibliografia sobre a matéria v. PBC, Aspectos legais do dinheiro, in Direito modemo em foco, de Irineu STRENGER (São Paulo, Ed. RT, 1986).

62. Obra básica nesse campo, que sempre vale referir é o já citado estudo coordenado por Rudolf B. SCHLESINGER, Formation of Contracts.

63. Novamente, neste passo, vale lembrar Antonio Junqueira de AZEVEDO (op. cit.).

64. V., a respeito, GORLA, La logica illogica del consensualismo (Riv. dir. civ., 1966).

65. O que, segundo Aldo FRIGNANI (op. cit., 60), no direito italiano, vem restabelecer o equilibrio entre "il vantaggio che la teoria della congnizione, accolta dal nostro codice, concede all'offrente rispetto all'ablato", observando a seguir que:

infatti nel sistema della LUFC la revoca dell'offerta e efficace soltanto in quanto dell'oblato, prima della spedizione dell'accettazione o prima del compimento di uno degli atti menzionati all'art. 6 (spedizione del bene o del prezzo), che corrispondono parzialmente all'inizio di esecuzione di cui all'art. 1327 c.c.it.

66. V. Sem. CCI: FCRPC, session 1.9 'definition of the law applicable to the precontractual relationship'. Para análise detalhada das Convenções em matéria de venda internacional, v. H. LESGUILLONS, Contrats internationaux (op. cit., quarta div. 'la vente internationale'). 105).

67. Lord STOWELL, Darhymple v. Darhymple (1811) (2 Hag. Con. 54 at

68. Sobre a consideration, v. infra, cap. IX.

69. Lord DENNING (op. cit., pp. 50/53).

70. CHESHIRE, FIFOOT \& FURMSTON's Law of Contract (London, Butterworths, 11th ed., 1986, pp. 106 ss.).

71. MERRIT v. MERRIT (1970) 2 A11 ER 760. (1970) 1 WLR 1211.

72. No mesmo sentido, v. tb.: Mc GREGOR v. Mc GREGOR (1888) 21 QBD 424 e PEARCE v. MERRIMAN (1904) 1 KB 80. 
73. $2 \mathrm{~KB}$ at $578-579$ (1918).

74. Judge ATKIN, v. supra, idem.

75. PETTITT v. PETTITT (1970) AC 777. (1969) 2 A11 ER 385.

76. V. supra, idem, at 822 e $413-414$.

77. JONES v. PADAVATTON (1969) 2 A11 ER 616. (1969) 1 WLR 328.

78. (1969) 1 WLR at 322. (1969) 2 A11 ER at 620. CHESHIRE, FIFOOT \& FURMSTON's (op. cit., p. 110) observam que ambos os juízes mencionaram e aplicaram BALFOUR v. BALFOUR.

79. (1969) 2 A11 ER at 623. (1969) 1 WLR at 335.

80. (1955) 3 A11 ER 10. (1955) 1 WLR 975.

81. V. CHESHIRE et al, Law of Contract (op. cit., pp. 111/115).

82. CARLLII v. CARBOLIC SMOKE BALL CO. (1893) 1 QB 256.

83. ROSE AND FRANK v. CROMPTON (1923) 2 KB 261; reversed (1925) AC 445 .

84. (1923) $2 \mathrm{~KB}$ at 288.

85. (1925) AC at 455. supra).

86. Por ex, no caso CARLLIL v. CARBOLIC SMOKE BALL CO. (cit.,

87. (1969) 2 A11 ER 481; (1969) 1 WLR 339.

88. Idem 86, supra.

89. O Industrial Relations Act, 1971, section 34, determinava que os acordos coletivos por escrito deveriam ser interpretados com presunção de executoriedade. Tal dispositivo parece ter tido efeitos práticos pouco consideráveis, considerando que a grande maioria dos acordos coletivos de trabalho previam expressamente que os mesmos não teriam força executória, o que, por sua vez, foi alterado pelo Trude Union and Labor Relations Act, 1974, com presunção contrária.

90. WILLINSTON, On Contracts (third ed., sect. 21).

91. WILLINSTON (op. cit., idem). 
92. CHESHIRE, FIFOOT \& FURMSTON's (op. cit., pp. 106/107).

93. CHESHIRE, FIFOOT \& FURMSTON's (op. cit., loc. cit.) observam:

English lawyers may well be prepared to accept the first two of these propositions: decided cases refute the third. But acceptance does not necessarily justify the complete rejection of intention to create legal relations as an independent element in the formation of contract. It is certainly true, and of great significance, that the very presence of consideration normally implies the existence of such an intention. To make a bargain is to assume liability and to invite the sanction of the Courts. Professor WLLINSTON performed a valuable service by insisting that the emphasis laid by foreign systems on this element of intention is out place in common law, where it follows naturally from the very nature of contract. Consideration, bargain, legal consequences - these are irrelated concepts. But it is possible for this presumption to be rebutted. If $A$ and $B$ agree to lunch together and $A$ promises to pay for the food if $B$ pay for the drink, it is difficult to deny the presence of consideration and yet equally clear that no legal ties are contemplated and created. It seems necessary, therefore, to regard the intention to create legal relations as a separate element in the English law of contract, though, by the preoccupation of that law with the idea of bargain, one wich does not normaly obtrude upon the courts. relations.

94. V. supra, os caps. sobre oferta, aceitação e intention to create legal

95. Para análise da evolução do direito inglês, as fontes foram: C.H.S FIFOOT, History and the Sources of Common Law: Tort and Contract (1949), J.H. BAKER, An Introduction to English Legal History (second ed., 1979) e G. CRISCUOLI, Introduzione allo studio del diritto inglese - le fonti (Milano, Giuffre Ed., 1981, prefácios sobre 'il valore del diritto inglese come dato di comparazione', de X.BLANC-JOUVAIN, LJ. CONSTANTINESCO, J.L. DE LOS MOZOS, P. GROSSI, K. LIPSTEIN e P. RESCIGNO).

96. Caso julgado em 1778 pela Câmara dos Lordes.

97. René DAVID e David PUGSLEY (avec la collaboration de Françoise Grivart de KERSTRAT), Les contrats en droit anglais (Paris, LGDJ, 2eme. ed., 1985, pp.94 ss.).

98. René DAVID e David PUGSLEY (op. cit., loc. cit.).

99. René DAVID e David PUGSLEY (op. cit., loc. cit.).

100. René DAVID e David PUGSLEY (op. cit., loc. cit.).

101. POLLOCK, On Contract (13th. ed., cit). 
102. POLLOCK (op. cit, pp. 133 ss.).

103. DUNLOP v. SELFRIDGE (1915)AC 847.

104. René DAVID e David PUGSLEY (op. cit., loc. cit.).

105. HART v. MILLS(1846) $15 \mathrm{M}$ and W 85.

106. V. supra, nota 82 e o cap. precedente.

107. René DAVID e David PUGSLEY (op. cit., loc. cit.).

São Paulo, 27 de agosto de 1990. 